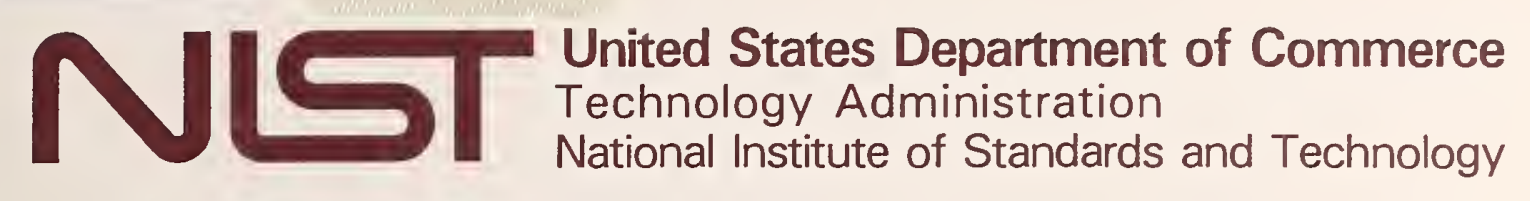

NIST Technical Note 1364

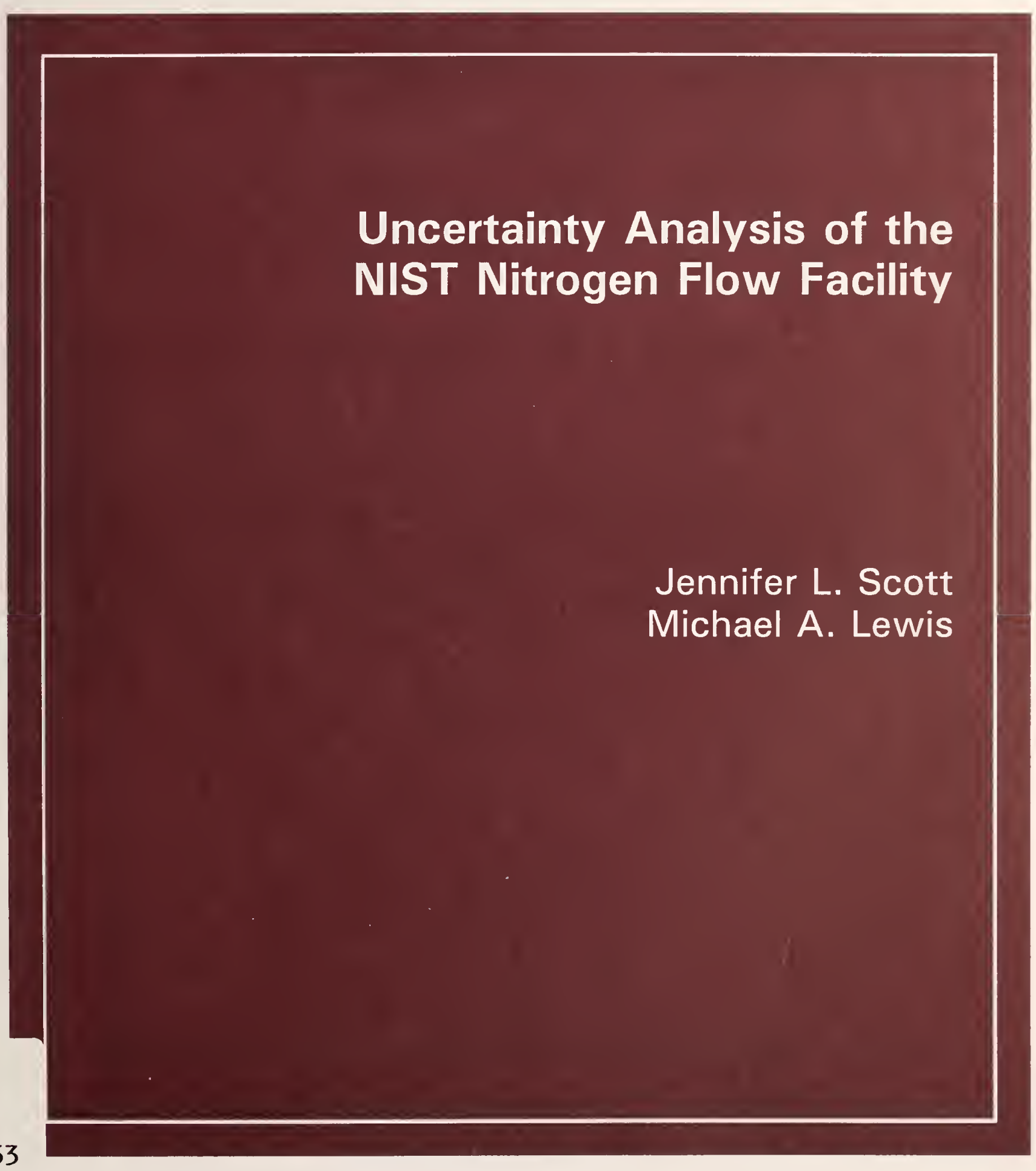

QC

100

.45753

N0.1364 



\title{
Uncertainty Analysis of the NIST Nitrogen Flow Facility
}

\author{
Jennifer L. Scott \\ Michael A. Lewis
}

Process Measurements Division

Chemical Science and Technology Laboratory

National Institute of Standards and Technology

325 Broadway

Boulder, Colorado 80303-3328

Supersedes NBS TN 606

March 1994

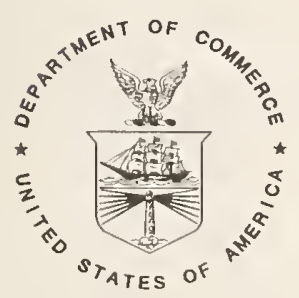

U.S. DEPARTMENT OF COMMERCE, Ronald H. Brown, Secretary TECHNOLOGY ADMINISTRATION, Mary L. Good, Under Secretary for Technology NATIONAL INSTITUTE OF STANDARDS AND TECHNOLOGY, Arati Prabhakar, Director 
National Institute of Standards and Technology Technical Note Natl. Inst. Stand. Technol., Tech. Note 1364, 48 pages (March 1994) CODEN:NTNOEF

\section{U.S. GOVERNMENT PRINTING OFFICE WASHINGTON: 1994}

For sale by the Superintendent of Documents, U.S. Government Printing Office, Washington, DC 20402-9325 


\section{CONTENTS}

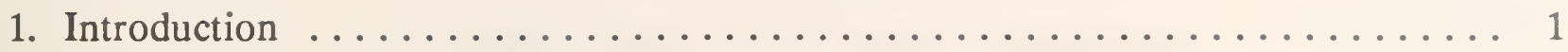

2. Uncertainty Evaluation $\ldots \ldots \ldots \ldots \ldots \ldots \ldots \ldots \ldots \ldots \ldots \ldots \ldots \ldots \ldots \ldots$

3. Liquid Nitrogen Flow Facility $\ldots \ldots \ldots \ldots \ldots \ldots \ldots \ldots \ldots \ldots$

3.1 Facility Description ......................... 4

3.2 Uncertainty in Liquid Nitrogen Mass Flow Measurement ... . . . . . . . 6

3.2.1 Load Cell Sensitivity .................... 6

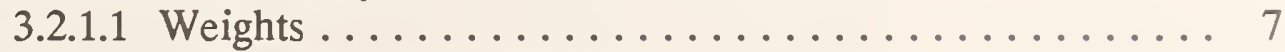

3.2.1.2 Voltage ......................... 7

3.2.1.3 Sensitivity Equation ............... 7

3.2.1.4 Pressure ..................... 8

3.2.2 Buoyancy Correction .................. 8

3.2.2.1 Volume of Liquid in Weigh Tank .......... 9

3.2.2.2 Density of Nitrogen-Helium Ullage .......... 10

3.2.2.3 Volume of Diffuser and Pipe .............. 11

3.2.2.4 Liquid Volume Accumulated before Measurement .... 11

3.2 .3 Time . . . . . . . . . . . . . . . . . . . 12

3.2.4 Volume between Test Section and Weigh Tank ........ 12

3.3 Liquid Volume Flow Rate Measurement . . . . . . . . . . . . 13

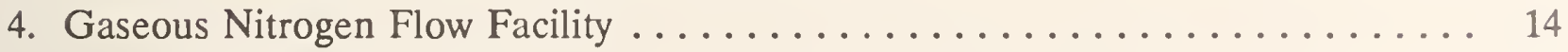

4.1 Facility Description .......................... 14

4.2 Uncertainty in Gaseous Nitrogen Mass Flow Measurement ... . . . . . 16

4.2.1 Weigh Tank Uncertainty .................. 16

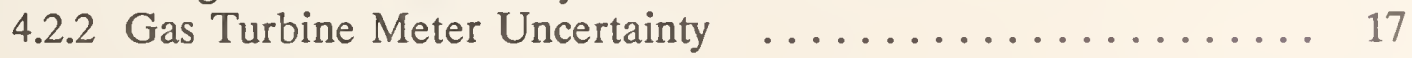

4.2.2.1 Calibration Equation ................ 18

4.2.2.2 Mass ......................... 18

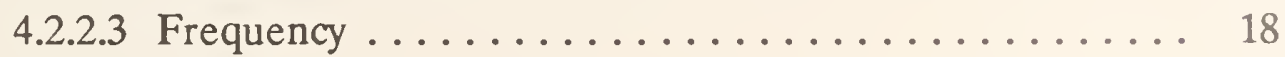

4.2.2.4 Density ......................... 19

4.3 Uncertainty in Orifice Meter Discharge Coefficient .......... 20

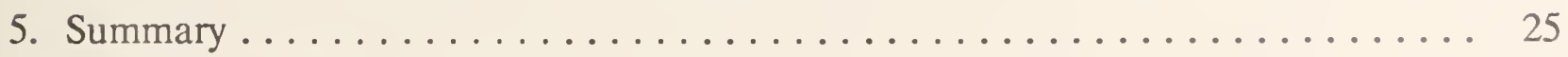

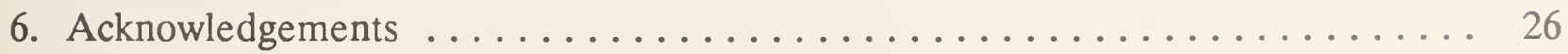

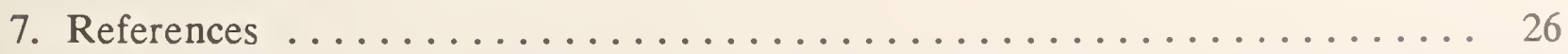


APPENDIX A. LOAD CELL CALIBRATION WEIGHTS REPORTS AND UNCERTAINTIES ....................

APPENDIX B. NITROGEN PROPERTY UNCERTAINTY . . . . . . . 31

APPENDIX C. UNCERTAINTIES IN ELECTRONIC

INSTRUMENTATION . ............... 32

APPENDIX D. UNCERTAINTIES OF QUARTZ BOURDON GAUGES

USED AS CALIBRATION PRESSURE STANDARD . . . . 34

APPENDIX E. UNCERTAINTIES IN PRESSURE SENSING

INSTRUMENTS .................... 35

APPENDIX F. UNCERTAINTIES IN TEMPERATURE

MEASUREMENT ................... 40

APPENDIX G. UNCERTAINTIES IN DIMENSIONAL MEASUREMENTS . 44 


\title{
Uncertainty Analysis of the NIST Nitrogen Flow Facility
}

\author{
Jennifer L. Scott and Michael A. Lewis \\ National Institute of Standards and Technology \\ Chemical Science and Technology Laboratory \\ Boulder, Colorado 80303
}

\begin{abstract}
An uncertainty analysis of the nitrogen flow facility at the National Institute of Standards and Technology was performed. This facility functions as a cryogenic flow calibration laboratory and as an applied research laboratory for high pressure nitrogen gas flow measurement. This report includes the analysis of uncertainty in liquid nitrogen mass flow, gaseous nitrogen mass flow determined by a system turbine meter, instrumentation, and the uncertainty in orifice meter discharge coefficient calculation using a defined propagation of uncertainties technique. Uncertainties determined by statistical means are distinguished from those determined by other means.
\end{abstract}

Key words: buoyancy; density; discharge coefficient; mass; propagation of uncertainties; orifice meter; sensitivity; statistics; turbine meter; Type A uncertainty, Type B uncertainty

\section{Introduction}

This report provides a detailed description of the uncertainty analysis of the nitrogen flow facility at the National Institute of Standards and Technology (NIST) in Boulder, Colorado. This facility is used in two distinct ways. We calibrate and/or test cryogenic flowmeters using a mass and time dynamic weigh system. After a system modification, we can conduct applied research on gas flowmeters using the same weigh system. We focus the uncertainty analysis in two areas: (1) the uncertainty associated with the determination of mass flow rate, and (2) the uncertainty in measuring orifice meter discharge coefficients in nitrogen gas flow.

\section{Uncertainty Evaluation}

We use the guidelines in NIST Technical Note 1297 [1] to classify the types of uncertainties in our facility and to determine their values. We distinguish the components of uncertainty determined by statistical analysis of observed data, called Type A, from those determined by a priori information (for example, manufacturers' uncertainties for electronic equipment), Type B.

Nearly all samples used to estimate Type A uncertainties contain more than 30 points. Most Type B uncertainties are those associated with instrumentation and thermophysical properties. of the working fluids (liquid and gaseous nitrogen) where the number of degrees of freedom is considered infinite. Following the guideline in Technical 
Note 1297 , we assume that uncertainties stated by manufacturers are based on a rectangular distribution; that is, the performance of the instrument will fall within the manufacturers' uncertainty 100 percent of the time. To estimate a standard uncertainty of an instrument, we divide the manufacturer's uncertainty by the square root of 3 .

The combination of all uncertainties, in quadrature, is multiplied by a coverage factor of 2 in order to estimate an approximate 95 percent confidence interval for total system uncertainty. All sample sizes were large enough that a coverage factor of 2 is sufficient to estimate a 95 percent confidence interval.

The key to determining the uncertainty in our system centers on our ability to determine the uncertainty in crucial measurements of temperature, pressure, frequency, and mass. Certain electronic instruments are common to many of these measurements. Our analyses of the uncertainties in these instruments, as well as the uncertainties in density computation and dimensional measurements, are included in the Appendices. The Appendices also contain uncertainty analyses of pressure and temperature measurements. The information in these Appendices lays the groundwork for determining uncertainties in measurements involving combinations of these values.

A first-order Taylor series expansion, commonly called propagation of uncertainty, is used to determine the uncertainties in a quantity (such as, discharge coefficient) that is calculated when the variables in the calculation have associated uncertainties. Equations (1) and (2) show the general form used in evaluating propagation of uncertainties,

$$
\begin{gathered}
y=f\left(x_{1}, x_{2}, \ldots x_{n}\right), \\
u_{c}^{2}(y)=\sum_{i=1}^{n}\left[\frac{\delta f}{\delta x_{i}}\right]^{2} u^{2}\left(x_{i}\right)+2 \sum_{i=1}^{n-1} \sum_{j=i+1}^{n} \frac{\delta f}{\delta x_{i}} \frac{\delta f}{\delta x_{j}} u\left(x_{i}, x_{j}\right),
\end{gathered}
$$

where y represents a quantity that is calculated as a function of $\mathbf{n}$ other quantities, $\mathbf{x}_{\mathrm{i}}, \ldots \mathrm{x}_{\mathrm{n}}$, and $u_{c}(y)$ is the combined standard uncertainty of the calculated quantity. The third term in Equation (2) represents the covariance between variables.

To determine uncertainties in many components of the flow system we combine factors as though their relationship was multiplicative; that is, we sum the squares of the individual uncertainties. Whenever the functional relationship can be determined, we use the propagation of uncertainty. We do not include covariances because in no case did we determine that the uncertainty of one factor was a function of the uncertainty in another factor. The following list describes notations used in this report. 
Notation:

Type A Uncertainty determined by statistical means

Type B Uncertainty determined by other means

n Sample size

$\mathrm{k}$ A coverage factor that is multiplied by the combined standard uncertainty to achieve a 95 percent confidence interval estimate for total uncertainty. This product is called the expanded uncertainty, and in this analysis, $\mathrm{k}$ equals 2.

quadrature $\left(a^{2}+b^{2}+\ldots .\right)^{1 / 2}$, root sum of the squares

$\mathrm{u}\left(\mathrm{x}_{\mathrm{i}}\right)$ Estimate of the standard uncertainty $(1 \sigma)$ of the variable $\mathrm{x}_{\mathrm{i}}$

residual standard Standard deviation of the mean of the difference between known deviation values and those predicted by a model; root mean squared error

standard error $s / \sqrt{n}$, standard deviation of the mean divided by the square root of of the mean the sample size

$\mathrm{T}$ Temperature, $\mathrm{K}$

V Voltage, $\mathrm{V}$

I Current, A

$\rho$ Density, $\mathrm{kg} / \mathrm{m}^{3}$

CY The product of the orifice meter discharge coefficient and the expansion factor. This product is referred to as the discharge coefficient in this document.

m Mass, $\mathrm{kg}$

$\mathrm{t}$ Time, $\mathrm{s}$

$\Delta \mathrm{p}$ Differential pressure; pressure drop across an orifice plate, $\mathrm{kPa}$

static pressure Thermodynamic or line pressure, $\mathrm{Pa}$

D Internal pipe diameter, $\mathrm{cm}$

d Orifice bore diameter, $\mathrm{cm}$

$\mathrm{Fa}$ Coefficient of thermal expansion for stainless steel

$\beta$ Beta ratio, ratio of the orifice bore to the pipe diameter (d/D)

test point This phrase describes one mass measurement by either the weigh tank or a turbine meter. It may include any or all of the following additional measurements: elapsed time, pulses, temperatures, and pressures.

Y Expansion factor 


\section{Liquid Nitrogen Flow Facility}

\subsection{Facility Description}

The cryogenic liquid nitrogen facility, built by the National Bureau of Standards (NBS) and the Compressed Gas Association, was commissioned in 1968. A detailed description of the early capabilities and design information is given in NBS Report 9749 [2]. A provisional accuracy statement, NBS Technical Note 606 [3], was published in 1971 regarding the liquid nitrogen system. The present report describes slightly different techniques to evaluate uncertainty but relies on some of the results included in [3]. In addition, changes in instrumentation and data acquisition since the publication of Technical Note 606 require a new uncertainty evaluation. This section describes the hardware of the liquid facility and the measurements required for flowmeter calibrations.

Figure 1 is a schematic of the liquid flow facility. Liquid nitrogen is the process fluid which is circulated throughout the closed loop by a variable speed boost pump. The liquid flows into a subcooler where thermal energy due to pumping and ambient heat leak is removed. The temperature of the liquid nitrogen in the flow loop can be changed or controlled by adjusting the liquid level and the vapor pressure in the subcooler tank. Some of the test fluid also can be diverted around the subcooler, if necessary.

The path of the liquid nitrogen flow is shown in Figure 1. After leaving the centrifugal pump, the liquid nitrogen passes through the subcooler and/or bypass, through a vacuum-jacketed loop to the test section, and into a diffuser which removes the vertical component of velocity at the bottom of a $0.378 \mathrm{~m}^{3}(100 \mathrm{gal})$ aluminum weigh tank. The liquid flows through a valve at the bottom of the weigh tank and into a stainless steel pressure vessel with a $0.443 \mathrm{~m}^{3}$ (117 gal) usable capacity. When the temperatures and pressure in the system have reached a steady state condition, the weigh tank valve is closed and liquid nitrogen accumulates in the weigh tank.

Once the liquid reaches a preset level in the weigh tank, a test point begins. A timer is initiated and a computer begins storing digitized information about the system and any flow measurement device installed. For example, if a flowmeter with a frequency output is installed in the test section, a counter begins totalizing the meter pulses while the computer records digitized outputs from pressure transducers and thermometers. 


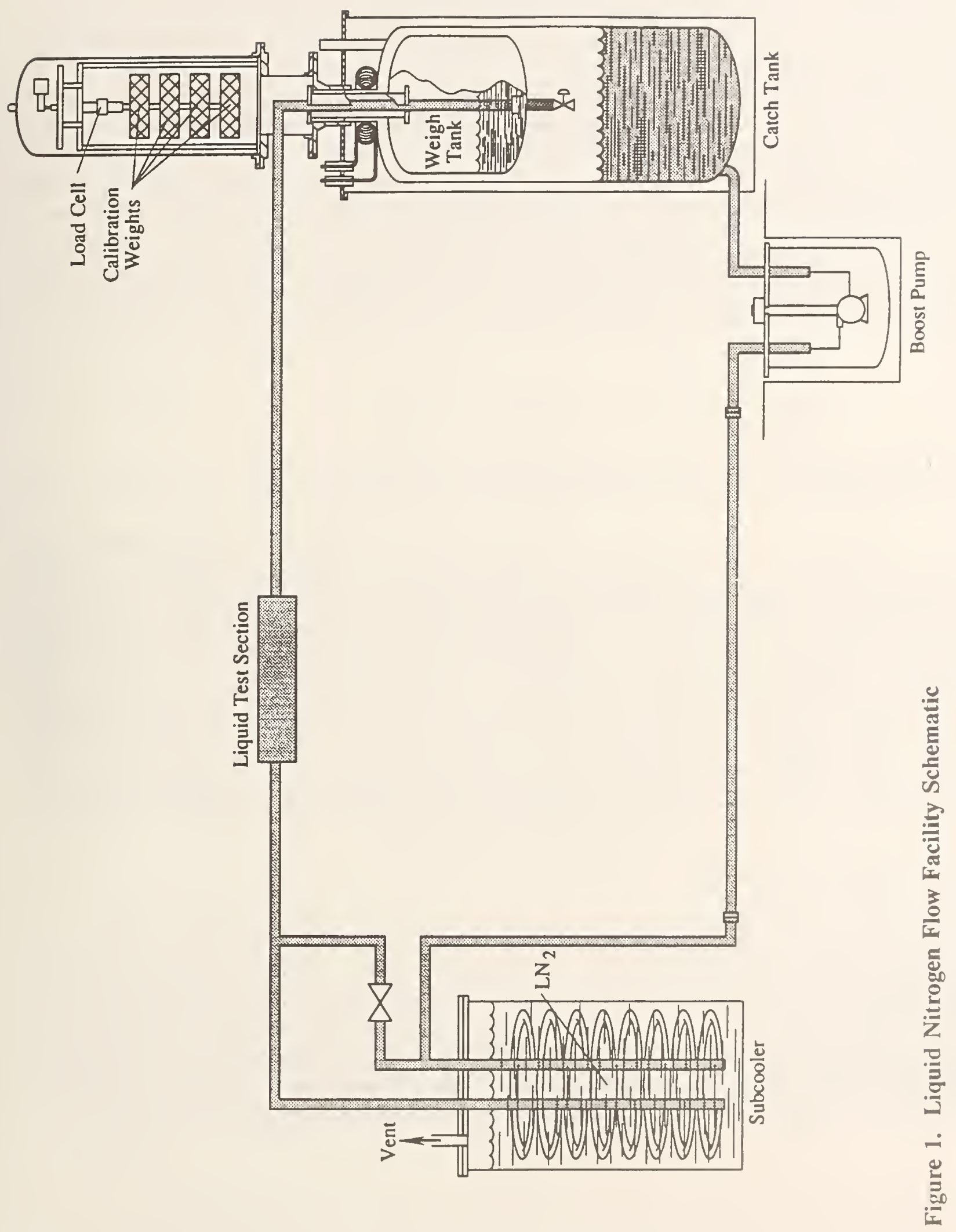


A second, preset liquid nitrogen level marks the end of the test point. Data acquisition stops and information from the timer and counters is sent to the main computer. A load cell is used to measure the mass of the liquid accumulated in the tank. The load cell output is recorded at the beginning and end of the test point so the difference in voltage is a measure of the accumulated mass. The load cell is calibrated by suspending NISTcalibrated weights on the load cell before flowmeters are tested.

Helium is used as an over-pressurant in the catch and weigh tanks to control the system pressure. The system is always over-pressurized to prevent boiling in the liquid nitrogen. The nitrogen is always subcooled by 10 to $15 \mathrm{~K}$. Helium absorption in the liquid nitrogen is expected not to exceed 0.5 mole percent according to data by DeVaney, Dalton, and Meeks [4]. No test points are taken if evidence of bubbles is detected visually through a sapphire window located near the meter being tested.

The continuous flow loop allows for the establishment of system temperature, pressure, and flow rate with the capability to maintain steady conditions for substantial time periods. Typical calibration parameters are:

Flow rate: 0.95 to $9.5 \mathrm{~kg} / \mathrm{s}$ (2 to $20 \mathrm{lb} / \mathrm{s}$ )

Pressure: 0.4 to $0.76 \mathrm{MPa}$ (60 to $110 \mathrm{psia}$ )

Temperature: 80 to $90 \mathrm{~K}\left(144\right.$ to $\left.162^{\circ} \mathrm{R}\right)$

\subsection{Uncertainty in Liquid Nitrogen Mass Flow Measurement}

The heart of our flow measurement facility is the weigh tank system. When we calibrate cryogenic mass flowmeters, the uncertainty in the calibration data is equal to the uncertainty in our mass flow measurement. The uncertainty in a calibration of a cryogenic volume flowmeter depends on our ability to measure mass flow and liquid test-section density. When we calculate the uncertainty in the discharge coefficient of an orifice flowmeter, the uncertainty in mass flow is an integral portion of the propagation of uncertainties associated with this calculated quantity. Consequently, we have included a detailed description of our calculation of uncertainty in mass measurement. The components of mass uncertainty include those from the load cell, the buoyancy corrections, time measurement, and changing mass between the test section and the weigh tank. Percent uncertainties are based on a $181.4 \mathrm{~kg}(400 \mathrm{lb})$ test draft.

\subsubsection{Load Cell Sensitivity}

The mass of the liquid is measured by a load cell. The load cell is calibrated by applying a series of certified weights on the load cell and measuring the output. At every calibration point we measure both the excitation voltage $\left(\mathrm{E}_{\text {exc }}\right)$ to, and the output voltage $\left(E_{\text {out }}\right)$ from, the load cell before and after the weight is added. Also, we measure the pressure of the ullage surrounding the load cell. The sensitivity of the load cell at that point is calculated as a ratio of the change in weight to the difference in the voltage ratios before and after the weight is added. Equation (3) illustrates this calculation: 


$$
\text { Sensitivity }=\frac{\text { change in mass }}{\frac{E_{2 o u x}}{E_{2 e x c}}-\frac{E_{1 \text { out }}}{E_{\text {lexc }}}} .
$$

$\mathrm{E}$ is the symbol for measured voltage. The denominator will be called $\Delta \mathrm{E}$ in the remainder of this discussion even though it is a dimensionless quantity.

A sample of 144 of these sensitivities was fitted by regression versus $\Delta E$ and pressure. This fit creates a sensitivity 'surface' which is called the sensitivity equation in the following discussion. Even though it is nearly flat in the $\Delta \mathrm{E}$ plane, it is important that this variable be included in the regression fit. We calibrate the load cell at 3 discrete weights, but we must interpolate between these values during nitrogen flow measurement. The total uncertainty in the calculation of the sensitivity of the load cell, which is direct correlation to uncertainty in mass measurement, has four components: weights, voltage, sensitivity equation, and pressure.

\subsubsection{Weights}

The load cell calibration weights are four nominal $113.4 \mathrm{~kg}(250 \mathrm{lb})$ brass cylinders. The calibration documents and uncertainty information are given in Appendix A.

\subsubsection{Voltage}

Two digital voltmeters are used to measure the voltages associated with the load cell: one measures the nearly constant excitation voltage to the bridge of the load cell and the other measures the voltage from the leg of the bridge. All calculations using these voltages are in the form of $\Delta \mathrm{E}$, explained in Section 3.2.1. This quantity is a difference between voltage ratios. Because we are using the voltages in this manner and not relying on the absolute values of voltage, we do not include the uncertainties associated with the digital voltmeters. Random uncertainties in the instruments will be reflected in the data points used in the calibration fit for the sensitivity function.

\subsubsection{Sensitivity Equation}

The uncertainty associated with the equation used in the computation of sensitivity is the ratio of residual standard deviation of the fit to a nominal value of sensitivity and is 0.050 percent. The nominal value chosen was the mean of the 144 data points used in the fit. The sensitivity, a measure of the load cell output as a function of the change in added weight, is nearly constant. Areas of uncertainty associated with the load cell are difficult or impossible to evaluate in situ. These components include randomness in the digital voltmeters (see Section 3.3.2), the repeatablilty of the load cell, and the static uncertainty in the calibration. The uncertainty associated with the equation includes many of these components. 
The form of the sensitivity equation also accounts for dynamic uncertainties in the load cell signal. During load cell calibration, we suspend three discrete weights from the load cell. During a data point, the weight on the load cell is varying dynamically as the weigh tank is being filled with liquid nitrogen. We do not evaluate the possible uncertainty in the load cell due to these dynamic conditions. The only way to quantify these dynamic uncertainties would be through a reference meter; however, the magnitude of the dynamic uncertainty would be orders of magnitude smaller that the uncertainty associated with any reference meter.

\subsubsection{Pressure}

The uncertainty associated with the pressure measurement contributes to the uncertainty in the sensitivity because it is an independent variable in the sensitivity equation. The uncertainty evaluation for the ullage pressure transducer, P9, is included in Appendix E. Using the propagation of uncertainties technique shown in Section 2, we assessed the additional uncertainty in sensitivity due to pressure at $10^{-9}$ percent, essentially zero. Table 1 lists the uncertainties associated with the load cell sensitivity.

Table 1. Load Cell Sensitivity Uncertainty (1 $\sigma$ )

\begin{tabular}{|c|c|c|}
\hline Uncertainty in Sens. & Type A & Type B \\
\hline Equation & $0.050 \%$ & \\
\hline Weights & & $0.002 \%$ \\
\hline Total (in quadrature) & $0.050 \%$ & $0.002 \%$ \\
\hline
\end{tabular}

\subsubsection{Buoyancy Correction}

The buoyancy of the mass of liquid nitrogen collected in the weigh tank must be evaluated for every mass measurement. There are three components to the correction in mass measurement due to buoyancy: (1) the buoyancy of the liquid nitrogen accumulated during the data point, (2) the buoyancy of the immersed diffuser and pipe in the liquid, and (3) the change in buoyancy of the liquid nitrogen accumulated before the data point begins. The first two are reflected in the equation

$$
\text { B.C. }=V_{\text {liq }} * \rho_{\text {ullage }}-V_{\text {pipe }} * \rho_{\text {liq }} \text {, }
$$

where B.C. is the correction due to buoyancy, $V_{\text {liq }}$ is the volume of the liquid nitrogen accumulated during a data point, $\rho_{\text {ullage }}$ is the density of the catch tank ullage, $V_{\text {pipe }}$ is the volume of the diffuser and pipe immersed in the liquid nitrogen, and $\rho_{\text {liq }}$ is the density of the liquid nitrogen. The propagation of uncertainty for the buoyancy correction equation follows: 


$$
\begin{aligned}
& \begin{array}{c}
u(B . C .)^{2}=\left(\rho_{\text {ullage }} * u\left(V_{\text {liq }}\right)\right)^{2}+\left(V_{\text {liq }} * u\left(\rho_{\text {ullage }}\right)\right)^{2} \\
+\left(-V_{p i p e} * u\left(\rho_{\text {liq }}\right)\right)^{2}
\end{array} \\
& u\left(V_{l q q}\right)^{2}=\left(-\frac{\text { mass }}{\rho_{l i q}^{2}} * u\left(\rho_{u q}\right)\right)^{2}, \\
& \begin{aligned}
u(B . C .)^{2}=\left(\rho_{\text {ullage }}\right. & \left.* \frac{\text { mass }}{\rho_{\text {liq }}{ }^{2}} * u\left(\rho_{\text {liq }}\right)\right)^{2}+\left(V_{\text {liq }} * u\left(\rho_{\text {ullage }}\right)\right)^{2} \\
& +\left(-V_{\text {pipe }} * u\left(\rho_{\text {liq }}\right)\right)^{2} .
\end{aligned}
\end{aligned}
$$

The first term on the right side of the equation represents the uncertainty in the buoyancy due to liquid nitrogen density as it relates to liquid nitrogen volume; the second, due to the catch tank ullage density; and the third due to liquid density as it relates to the immersed pipe and diffuser. Each of these components will be addressed in the following sections, as will the effect of the change in buoyancy of the liquid nitrogen accumulated before the data point begins. The uncertainty calculations that follow represent the effect that these uncertainties have on a nominal $181.4 \mathrm{~kg}$ mass.

\subsubsection{Volume of Liquid in Weigh Tank}

Our ability to determine the volume of the accumulated liquid nitrogen is a direct result of our ability to evaluate the pressure, temperature, and, thereby, density of liquid nitrogen. The uncertainty in the pressure (P9 and barometer) and temperature (T13) measurement in the weigh tank are found in Appendices E and F. Appendix B outlines our uncertainty evaluation for liquid nitrogen density. It includes the uncertainty in MIPROPS, the property software we use $[5,6]$, as well as the uncertainty in density due to uncertainties in temperature and pressure measurements. Using a 38-point data sample, we have evaluated the effect of these density uncertainties on a nominal $181.4 \mathrm{~kg}$ mass. The results are shown in Table 2. 
Table 2. Uncertainties ( $1 \sigma)$ in Mass Measurement Caused by Uncertainties in Liquid Density

\begin{tabular}{|c|c|c|}
\hline \multirow{2}{*}{$\begin{array}{l}\text { Source of Uncertainty in } \\
\text { Liquid Density }\end{array}$} & Percent change in a nominal $181.4 \mathrm{~kg}$ mass \\
\cline { 2 - 3 } & Type A & Type B \\
\hline MIPROPS & & $0.004 \%$ \\
\hline$\delta \rho /\left.\delta \mathrm{T}\right|_{\mathrm{P}}(\sigma=0.5 \mathrm{~K})$ & & $0.006 \%$ \\
\hline$\delta \rho /\left.\delta \mathrm{P}\right|_{\mathrm{T}}(\mathrm{P} 9$, Baro $)$ & $0 \%$ & $0 \%$ \\
\hline Total (in quad) & $0 \%$ & $0.007 \%$ \\
\hline
\end{tabular}

\subsubsection{Density of Nitrogen-Helium Ullage}

The two most important factors in determining the density of the $\mathrm{He}-\mathrm{N}_{2}$ mixture are the temperature of the ullage in the volume surrounding weigh tank and the model used to estimate the density of this mixture.

We use the Redlich-Kwong model, as modified by Chueh and Prausnitz, for the binary equation-of-state calculation [7]. This model uses the catch tank ullage temperature and pressure, and the liquid nitrogen temperature as input. When this model was adapted to our system, empirical tests by NIST personnel led to an estimate of 3 to 5 percent uncertainty in the ullage mixture density calculation using this model. Using a 38-point sample of archival data, we determined the effect of the buoyancy correction on a $181.4 \mathrm{~kg}$ mass measurement if the ullage density deviated by 4 percent. This value is shown in Table 3.

We also determined the sensitivity of this model to uncertainties in temperature and pressure measurement. Three temperature measurements are involved in computing the ullage density: the two ullage thermometers (TS71 and TS72) and the liquid nitrogen thermometer (T13). The liquid nitrogen temperature is required to determine vapor pressure. The uncertainties associated with these thermometers are shown in Appendix F, and those for pressure are shown in Appendix E. These uncertainties in temperature and pressure affect the ullage density calculation and, therefore, the mass measurement. The resultant uncertainties on a $181.4 \mathrm{~kg}$ mass are shown in Table 3. 
Table 3. Uncertainties (1 $1 \sigma$ ) in Mass Measurement Caused by Uncertainties in Ullage Density

\begin{tabular}{|c|c|c|c|}
\hline \multirow{2}{*}{$\begin{array}{l}\text { Source of Uncertainty in } \\
\text { Ullage Density }\end{array}$} & \multicolumn{2}{|c|}{ Percent change in a nominal $181.4 \mathrm{~kg}$} & mass \\
\hline & Type A & Type B & \\
\hline Redlich-Kwong (4\%) & & $0.063 \%$ & \\
\hline $\begin{array}{l}\delta \rho /\left.\delta \mathrm{T}\right|_{\mathrm{P}}(\sigma=1 \mathrm{~K}) \\
\mathrm{TS} 71, \mathrm{TS} 72\end{array}$ & & $0.018 \%$ & \\
\hline $\begin{array}{l}\delta \rho /\left.\delta \mathrm{T}\right|_{\mathrm{P}} \quad(\sigma=0.5 \mathrm{~K}) \\
\mathrm{T} 13\end{array}$ & & $0.006 \%$ & \\
\hline$\delta \rho /\left.\delta \mathrm{P}\right|_{\mathrm{T}}(\mathrm{P} 9$, Baro $)$ & $0.0001 \%$ & $0.0002 \%$ & \\
\hline Total (in quad) & $0.0001 \%$ & $0.066 \%$ & \\
\hline
\end{tabular}

\subsubsection{Volume of Diffuser and Pipe}

The mass must also be corrected for the buoyancy of the diffuser and pipe that are immersed in the collected liquid. The uncertainty in the correction is a function of the volume of the diffuser and pipe, and the density of the liquid in the weigh tank. We use the maximum diffuser and pipe volume that can be immersed in the liquid to provide the most conservative estimate of uncertainty due to the buoyancy correction of the pipe and diffuser. For that reason, we do not evaluate the effect on the buoyancy correction due to our uncertainty in measuring the volume of the pipe and diffuser. We evaluated the effect of a 0.5 percent uncertainty in density to the buoyancy correction for the pipe and diffuser and assessed its contribution to the uncertainty in a $181.4 \mathrm{~kg}$ mass. The result was 0.0035 percent. Because we did not determine this value by statistical means, it is a Type B uncertainty.

\subsubsection{Liquid Volume Accumulated before Measurement}

As explained in Section 3.1, a test point begins by closing the valve in the bottom of the weigh tank. When the accumulated mass reaches a preset level, 'level A,' data acquisition begin. At the end of the point, 'level B,' the mass is determined via the difference in load cell signals between 'level A' and 'level B.' Our analysis shows that the buoyancy of the liquid accumulated before the test point begins may change because the catch tank ullage temperatures surrounding this volume may change. We correct for this change in buoyancy, but due to the uncertainties (Type B) associated with thermometers T13, TS71, and TS72, we estimate an added 0.01 percent uncertainty in measuring a 181.4 $\mathrm{kg}$ mass due to this effect.

Table 4 lists all the uncertainties in mass measurement due to uncertainties in buoyancy corrections. 
Table 4. Mass Uncertainties ( $1 \sigma$ ) Caused by Buoyancy Corrections

\begin{tabular}{||l|l|l||}
\hline $\begin{array}{l}\text { Mass Uncertainty due to } \\
\text { Buoyancy Corrections }\end{array}$ & Type A & Type B \\
\hline Source: Liquid Density & & $0.012 \%$ \\
\hline Source: Ullage Density & $0.0001 \%$ & $0.066 \%$ \\
\hline Source: Diffuser/Pipe Vol & & $0.0035 \%$ \\
\hline Source: Volume Before Point & & $0.01 \%$ \\
\hline Total (in quadrature) & $0.0001 \%$ & $0.068 \%$ \\
\hline
\end{tabular}

\subsubsection{Time}

In most cases, mass flow rate is used for meter calibration. A multi-function datalogger is used to measure elapsed time. The uncertainty in time measurement is equal to the resolution, $0.001 \mathrm{~s}$. The contribution of time to the uncertainty in mass flow rate is evaluated at a nominal time of $100 \mathrm{~s}$. This is a Type B uncertainty.

Table 5. Uncertainty (10) in Mass Flow Rate Caused by Time

\begin{tabular}{|c|c|}
\hline Time Uncertainty & Type B \\
\hline $0.001 \mathrm{~s} @ 100 \mathrm{~s}$ & $0.001 \%$ \\
\hline
\end{tabular}

\subsubsection{Volume between Test Section and Weigh Tank}

There is a finite volume of liquid nitrogen in the piping between the meter being calibrated and the weigh tank. A measure of the density gradient in the pipe is the difference between fluid temperature at the meter end, Point $\mathrm{A}$, and the weigh tank end of the volume, Point B. We did not evaluate changes in density due to pressure drop because there is no reason to believe that the pressure drop changes during a data point. If the density gradient in this pipe remains constant during the data point, we assume that the mass collected in the weigh tank is equivalent to the mass passing through the meter.

We evaluated changes in the density gradient in this volume for eight data points. The average number of thermometer readings per data point was 165 . We plotted the difference between the temperature at the beginning of the pipe and the end of the pipe. For thermally stable flows, this difference is constant and the slope through a regression fit of these data is zero. A nonzero slope indicates that the density gradient and the mass in the pipe are changing.

We found that the average change in the temperature difference between Points $\mathbf{A}$ and $\mathrm{B}$ for the eight points evaluated was $0.067 \mathrm{~K}$ which translates to a 0.05 percent change 
in liquid nitrogen density (Appendix B). The density of liquid nitrogen at nominal values of $85 \mathrm{~K}$ and $586 \mathrm{kPa}$ is $773.02 \mathrm{~kg} / \mathrm{m}^{3}$. A 0.05 percent change in this density times a nominal volume of the piping $\left(0.05 \mathrm{~m}^{3}\right)$ results in a $0.019 \mathrm{~kg}$ mass change in the piping. The resultant uncertainty in a $181.4 \mathrm{~kg}$ mass measurement is 0.011 percent.

We did not include the uncertainties associated with the thermometers used in the evaluation. They are included in other areas where the absolute values of the temperature are needed. In this case, only the change in the difference between temperature measurements was evaluated and not the differences themselves. The random variation of the thermometers were accounted for in the regression fit of the temperature differences.

The following table exhibits all uncertainties associated with our measurement of mass and mass-flow rate.

Table 6. Total Uncertainties ( $1 \sigma)$ for Mass Measurement

\begin{tabular}{|l|c|c|c|}
\hline Source of Uncertainty: & Type A & Type B & Combined \\
\hline Load Cell Sensitivity & $0.050 \%$ & $0.002 \%$ & $0.050 \%$ \\
\hline Buoyancy Correction & $0.0001 \%$ & $0.068 \%$ & $0.068 \%$ \\
\hline $\begin{array}{l}\text { Mass between Test Section and } \\
\text { Weigh Tank (liquid } \mathrm{N}_{2} \text { ) }\end{array}$ & $0.011 \%$ & & \\
\hline Total for Mass Measurement & $0.051 \%$ & $0.068 \%$ & $0.085 \%$ \\
\hline Expanded Uncertainty, $\mathrm{k}=2$ & & $0.170 \%$ \\
\hline Time & & $0.001 \%$ & $0.001 \%$ \\
\hline Total for Mass Flow Rate & $0.051 \%$ & $0.085 \%$ \\
\hline Expanded Uncertainty, $\mathrm{k}=2$ & & $0.170 \%$ \\
\hline
\end{tabular}

\subsection{Liquid Volume Flow Rate Measurement}

Our ability to accurately measure liquid nitrogen volume flow rate through the test section depends not only on our ability to measure mass flow rate, but also on our determination of liquid density. The transducers used to evaluate the pressure and temperature of the liquid in the test section are P7 and T10. Their uncertainties are listed in Appendices $\mathrm{E}$ and $\mathrm{F}$. The uncertainties associated with density calculations are shown in Appendix B. Table 7 indicates the total uncertainty in determining liquid volume flow rate. Density uncertainties were evaluated for liquid nitrogen at $85 \mathrm{~K}$ and $620 \mathrm{kPa}$. 
Table 7. Uncertainty ( $1 \sigma)$ in Volumetric Flow Rate Measurement

\begin{tabular}{||c|c|c|}
\hline \multirow{2}{*}{$\begin{array}{l}\text { Source of Uncertainty in } \\
\text { Liquid Volume Flow }\end{array}$} & \multicolumn{2}{|c|}{$\begin{array}{l}\text { Nominal Values: } \mathrm{T}=85 \mathrm{~K}, \mathrm{P}=620 \mathrm{kPa}, \\
\text { Mass }=181.4 \mathrm{~kg}, \text { Time }=100 \mathrm{~seconds}\end{array}$} \\
\cline { 2 - 3 } & Type A & Type B \\
\hline MIPROPS & & $0.25 \%$ \\
\hline$\delta \rho /\left.\delta \mathrm{T}\right|_{\mathrm{P}}$ & $0.025 \%$ & $0.013 \%$ \\
\hline$\delta \rho /\left.\delta \mathrm{P}\right|_{\mathrm{T}}$ (P7,Baro) & $0.0002 \%$ & $0.0002 \%$ \\
\hline Uncert. in mass flow rate & $0.051 \%$ & $0.068 \%$ \\
\hline Total (in quad) & $0.057 \%$ & $0.259 \%$ \\
\hline Total (Type A+B, in quad), $\mathrm{k}=2$ & $0.531 \%$ \\
\hline Without MIPROPS uncertainty, $\mathrm{k}=2$ & $0.179 \%$ \\
\hline
\end{tabular}

The major contributor to the uncertainty of liquid nitrogen volumetric flow measurement is the uncertainty in the liquid density. The greatest uncertainty in density comes from the stated uncertainty in the equation of state (MIPROPS). When the objective of using the uncertainty statement is in the mediation between seller and buyer, where both have accepted the same values for density as determined by the NIST standard, the uncertainty in density due to the equation of state need not be considered. In that case, the expanded uncertainty in volumetric flow measurement for this laboratory (with $k=2$ ) is 0.18 percent.

\section{Gaseous Nitrogen Flow Facility}

The gaseous nitrogen flow loop has been used almost exclusively for applied orifice meter research. Much of the following discussion centers around our determination of uncertainty in orifice meter discharge coefficient.

\subsection{Facility Description}

A schematic of the gaseous nitrogen flow facility is shown in Figure 2. All of the components of the liquid system are used but, the flow is diverted as it leaves the circulating boost pump into a fixed speed centrifugal pressure pump which increases the pressure of the process fluid from 0.7 to $4.1 \mathrm{MPa}$ (100 to $595 \mathrm{psia}$ ). We always operate at pressures above 3.5 $\mathrm{MPa}$, the critical pressure of nitrogen; therefore, two-phase composition of the nitrogen is avoided. 


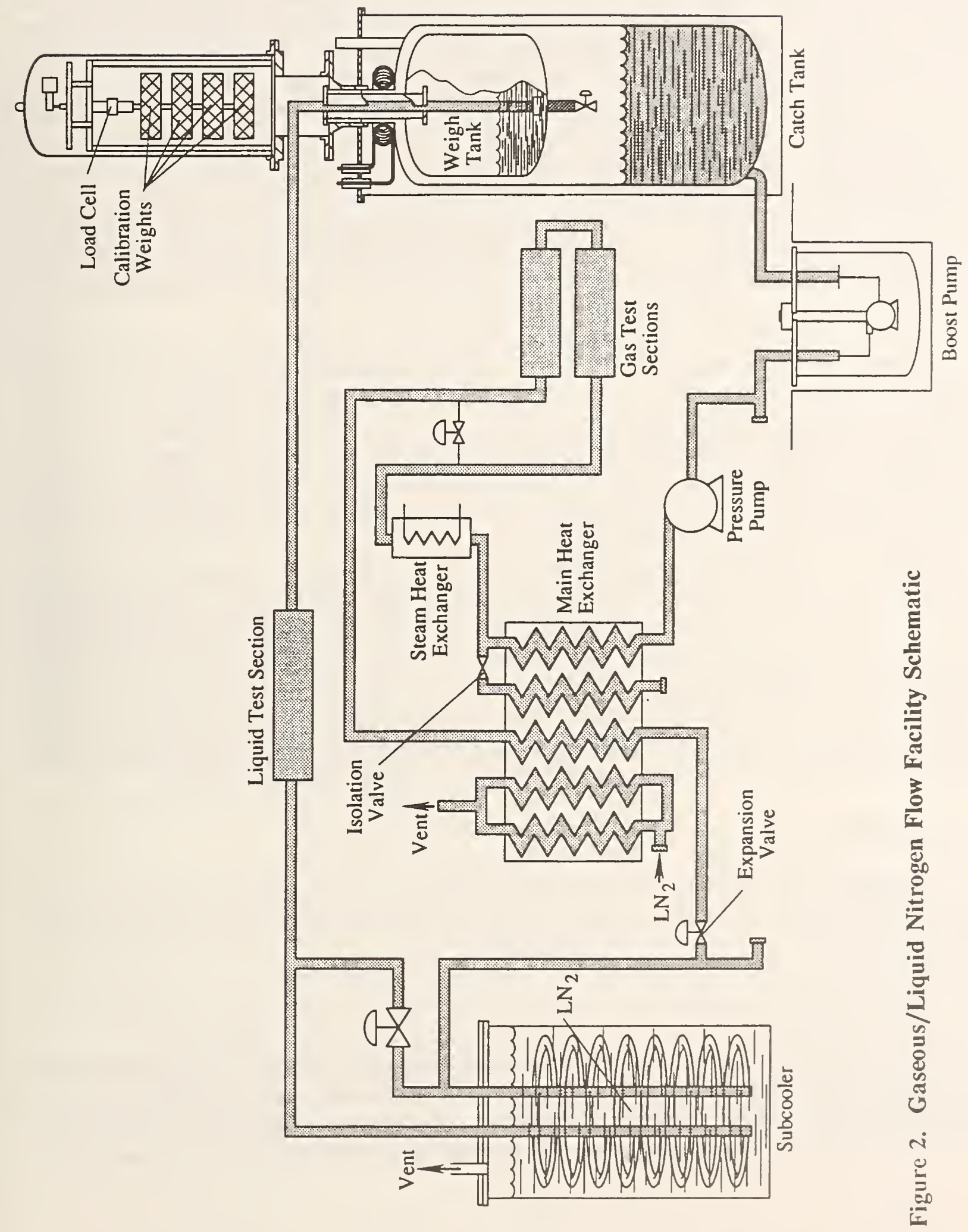


Thermal energy from three sources is added to the process fluid: (1) the ambient surroundings, (2) a large counterflow plate-fin heat exchanger, and (3) a shell and tube heat exchanger with steam on the tube side. The main heat exchanger is a five pass, plate-fin type, constructed of aluminum and insulated with a $30 \mathrm{~cm}$ thickness of polyurethane foam. The first pass in the main heat exchanger adds heat to the fluid through a counterflow process with the returning fluid. Downstream of the first pass in the main heat exchanger, a steam heat exchanger is used as a trim heater to control the temperature in the test section. The typical test section temperature is $288 \mathrm{~K}$. The process fluid returns through the second pass of the heat exchanger, counterflow to the first pass, removing heat from the return process stream. Two additional passages are used to exchange heat between subcooled liquid nitrogen and the returning process stream, removing additional thermal energy from the process stream. One passageway is closed and used as a gas thermometer (with pressure sensor) for heat exchanger monitoring and control purposes. If the pressure in the gas thermometer remains constant during a test point, then the temperature is constant and the rate of heat exchange is stable.

Process fluid flow is controlled by the operation of an expansion valve downstream of the main heat exchanger, in conjunction with the variable speed circulating pump. Additional thermal energy is removed downstream of the expansion valve with the liquid nitrogen bath subcooler mentioned in the liquid system description. At this point in the flow loop, the process fluid is liquid nitrogen and the load cell and reference described earlier are used to complete the flow loop. To maintain stable operation of this system, a minimum flow rate of approximately $0.5 \mathrm{~kg} / \mathrm{s}$ must be maintained and pressure drop in the gas loop must be minimized ( $<276 \mathrm{kPa}, 40 \mathrm{psia})$.

This is a complex thermodynamic cycle, and even though it is highly instrumented, it is difficult to quantify what is occurring at every element of the loop. The heat transfer in the main heat exchanger is the most difficult to describe, but stability in the enclosed gas thermometer reflects a stable heat exchange, that is, steady state flow, which is maintained throughout the test point. If this stability is maintained, the mass passing through a meter in the gas portion of the loop is equivalent to the mass being collected in the weigh tank during a data point. Because we can not quantify all uncertainties in this cycle, the gaseous nitrogen flow loop is used only for applied research and not for calibrations.

\subsection{Uncertainty in Gaseous Nitrogen Mass Flow Measurement}

We measure mass flow in the gaseous nitrogen flow loop with either the weigh tank described in Section 3.1 or by a gas turbine meter. The uncertainties associated with each are discussed.

\subsubsection{Weigh Tank Uncertainty}

The uncertainties in measuring mass flow rate with the weigh tank are explained fully in Section 3.2. The only difference between the analysis in Section 3.2 and the analysis provided here is the possible change in mass in the piping volume between the test section (gas versus liquid) and the weigh tank. If the system were totally stable, the mass in this 
volume would remain constant during a data point.

As we explained in the description of the gas flow facility in Section 4.1, the nitrogen in the piping between the gaseous nitrogen test section and the weigh tank is changed from supercritical, ambient temperature nitrogen to liquid nitrogen. It is safe to assume that during a $100 \mathrm{~s}$ test point, there may be some changes in density in subvolumes of this piping. This would not be true for test points in which we measure nitrogen gas flow with the turbines. The turbines are close to the orifice meter, and there is no phase change in the nitrogen fluid between them.

We measure and record pressures and temperatures at many locations between the test section and the weigh tank to quantify density changes in these subvolumes. We analyzed the changes in mass between the gas test section and the weigh tank as a function of these density measurements recorded over a period of several years. We estimate that the uncertainty (Type A) in a nominal mass of $181.4 \mathrm{~kg}$ due to the density variation in the piping is $0.03 \%$. Table 8 shows the uncertainties in gas measurement when using the weigh tank.

Table 8. Total Uncertainties (1 $1 \sigma)$ for Mass Measurement in Gaseous Nitrogen Loop Using Weigh Tank

\begin{tabular}{|l|c|c|c|}
\hline Source of Uncertainty: & Type A & Type B & Combined \\
\hline Load Cell Sensitivity & $0.050 \%$ & $0.002 \%$ & $0.050 \%$ \\
\hline Buoyancy Correction & $0.0001 \%$ & $0.068 \%$ & $0.068 \%$ \\
\hline $\begin{array}{l}\text { Mass between Test Section and Weigh } \\
\text { Tank (gas-liquid } \mathrm{N}_{2} \text { ) }\end{array}$ & $0.030 \%$ & & \\
\hline Total for Mass Measurement & $0.058 \%$ & $0.068 \%$ & $0.089 \%$ \\
\hline Expanded Uncertainty, $\mathrm{k}=2$ & & $\mathbf{0 . 1 7 9 \%}$ \\
\hline
\end{tabular}

\subsubsection{Gas Turbine Meter Uncertainty}

The minimum flow rate at which the gaseous nitrogen flow loop can operate is approximately $0.5 \mathrm{~kg} / \mathrm{s}$. We wanted to test orifice meters in the gas loop at lower flow rates, so we added two gas turbine meters in series upstream of the orifice meter. We bypass part of the flow before it enters the turbine-orifice meter loop so that total system flow is greater that $0.5 \mathrm{~kg} / \mathrm{s}$. One of the turbines is used as the primary measurement device, while the other serves as a constant reference to the primary turbine.

To determine the mass flow rate in the gas loop, the calibration curve for the primary turbine is used to determine the volumetric flow rate during the test point. The density and the mass flow rate are calculated using the temperature (T17) and the pressure (P17) measured at the turbine meter. The uncertainty in the mass flow rate calculated from the turbine meter is a combination of the uncertainties in the calibration equation, the counter 
measuring turbine meter pulses, the mass flow rates used in the calibration, and the density at the turbine meter.

\subsubsection{Calibration Equation}

We calibrated the turbine meters over the range of our gas flow mass-based system: 0.5 to $2.3 \mathrm{~kg} / \mathrm{s}(1.0$ to $5.0 \mathrm{lb} / \mathrm{s})$. The turbine meters and associated piping were then sent to an external facility to be calibrated over a flow rate range of 0.11 to $1.1 \mathrm{~kg} / \mathrm{s}(0.25$ to 2.4 $\mathrm{lb} / \mathrm{s})$. This calibration was done using air at pressures and temperatures similar to those at which our facility operates. The calibration report included a stated flow measurement uncertainty of 0.5 percent.

The calibration data sets from NIST and the external laboratory were dissimilar and difficult to resolve. The data set taken at the NIST laboratory contained 454 points and showed more scatter than the 40 points from the external laboratory calibration. We enlisted the help of the Statistical Engineering Division at NIST Boulder. They used a nonlinear fitting to simultaneously calculate the parameters of a two-line fit for volume flow rate versus frequency.

The calculation of uncertainty in the turbine meter calibration equation is not only a function of the calibration curve fit, but the uncertainty in the mass flow reference system of the facility performing the calibration and the density calculation. The turbine calibration curve fit relies more heavily on the data from the NIST calibration, and the standard uncertainty of the calibration is a reflection of the scatter from the NIST data. For these reasons, we chose the uncertainties associated with measuring mass, time, and density at the NIST lab to evaluate the uncertainty in the turbine meters.

The uncertainty in volumetric flow rate measured by the turbine meter due to the calibration curve fit alone, at a nominal value of $1.81 \mathrm{~kg} / \mathrm{s}$, is 0.20 percent.

\subsubsection{Mass}

The uncertainty in mass measurement was provided in section 4.2.1. We use only the Type B uncertainties here, because the Type A uncertainties are reflected in the calibration data scatter and are included in the calibration equation uncertainty. Type B uncertainty for mass measurement is 0.068 percent.

\subsubsection{Frequency}

The turbine frequency calculation is a combination of the output of the universal counter and the timer in the datalogger. A manual trigger at the beginning and the end of the measurement interval is used to signal measurements in both instruments. We totalize the pulses from the turbine meter, and no test point has fewer than 2500 pulses. Because the uncertainty in the counter is 1 pulse, the maximum uncertainty due to the counter is 0.04 percent. The Type B uncertainty in time measurement was shown in Section 3.2.3 to be 0.001 percent. 


\subsubsection{Density}

The calculated fluid density at the turbine meter is used to determine the mass flow rate in the gas flow loop. Table 9 lists the density uncertainties evaluated at the conditions noted, along with the other contributors to turbine meter uncertainty. As in Section 3.7, the expanded uncertainty is computed with and without the contribution of MIPROPS. The uncertainty in our measurements due to MIPROPS would not be considered if all parties were using the same property library.

Table 9. Uncertainty (1 $\sigma)$ in Mass Measurement Determined by the Turbine Meter

\begin{tabular}{||l|c|c||}
\hline \multirow{2}{*}{$\begin{array}{l}\text { Source of Uncertainty } \\
\text { in Turbine Mass Flow }\end{array}$} & \multicolumn{2}{|c|}{$\begin{array}{c}\text { Nominal Values: T=288.7 } \mathrm{K}, \mathrm{P}=3.87 \mathrm{MPa}, \\
\text { Mass }=181.4 \mathrm{~kg}, \text { Time }=100 \mathrm{~seconds}\end{array}$} \\
\cline { 2 - 3 } & Type A & Type B \\
\hline Calibration Eq. & $0.20 \%$ & $0.068 \%$ \\
\hline Uncert. in mass & & $0.040 \%$ \\
\hline Pulses & & $0.10 \%$ \\
\hline Density: MIPROPS & & $0.057 \%$ \\
\hline$\delta \rho /\left.\delta \mathrm{T}\right|_{\mathrm{P}}$ (T17) & $0.029 \%$ & $0.070 \%$ \\
\hline$\delta \rho /\left.\delta \mathrm{P}\right|_{\mathrm{T}}(\mathrm{P} 17$, Baro) & $0.026 \%$ & $0.156 \%$ \\
\hline Total (in quad) & $0.204 \%$ & $0.513 \%$ \\
\hline Expanded Uncertainty, $\mathrm{k}=2$ & $0.473 \%$ \\
\hline Without MIPROPS uncertainty, $\mathrm{k}=2$ & \\
\hline
\end{tabular}

The calculated uncertainty in mass measured by the turbine meter is more than twice that of mass measured by the weigh tank because it contains the uncertainty of the weigh tank as well as several other components (Section 4.2.2.1). When turbine-based mass flow rates are used in the calculation of orifice meter discharge coefficients, this additional uncertainty is not apparent. When we use both the turbine meter and the weigh tank to measure the same mass flow rate, the orifice meter discharge coefficients calculated using the turbine system calculated mass and those from the weigh tank system measured mass are indistinguishable. The major contribution to the turbine meter uncertainty comes from the curve fit to the calibration equation. The repeatability of turbine-based discharge coefficients is 0.1 to 0.15 percent. 


\subsection{Uncertainty in Orifice Meter Discharge Coefficient}

The uncertainty in discharge coefficient is calculated using the propagation of uncertainties technique described in Section 2. Most of the variables in the discharge coefficient equation represent values whose uncertainties are relatively insensitive to flow rate. This is not the case for the uncertainty associated with the differential pressure transducers. The description of uncertainty in the differential pressure transducers in Appendix E demonstrates this variability. Therefore, it is impossible to provide a single value for uncertainty in determining discharge coefficients.

The variables in the equation are mass, time, density, differential pressure, and pipe and orifice diameters. The only component of the discharge coefficient uncertainty that has not been explained in detail in previous sections or in the Appendices is the uncertainty in density. Table 10 outlines the components of density uncertainty at the orifice meter.

Table 10. Uncertainties (1 $\sigma$ ) in Gas Density at Orifice Meter

\begin{tabular}{||c|c|c|}
\hline \multirow{2}{*}{$\begin{array}{l}\text { Source of Uncertainty in } \\
\text { Orifice Gas Density }\end{array}$} & \multicolumn{2}{|c|}{ Evaluated at 3.79 $\mathrm{MPa}, 288.7 \mathrm{~K}$} \\
\cline { 2 - 3 } & Type A & Type B \\
\hline MIPROPS & & $0.10 \%$ \\
\hline$\delta \rho /\left.\delta \mathrm{T}\right|_{\mathrm{P}}(\mathrm{T} 16)$ & $0.031 \%$ & $0.057 \%$ \\
\hline$\delta \rho /\left.\delta \mathrm{P}\right|_{\mathrm{T}}(\mathrm{P} 16, \mathrm{Baro})$ & $0.039 \%$ & $0.055 \%$ \\
\hline Total (in quad) & $0.050 \%$ & $0.128 \%$ \\
\hline
\end{tabular}

The variables in the discharge coefficient equation are defined in Section 2. The term CY is the product of the discharge coefficient and the expansion factor Y. The equation used to calculate the expansion factor is found in metering standards and is associated with an uncertainty. The uncertainty we define for discharge coefficient is actually the uncertainty in our calculation of CY. The discharge coefficient equation and the method used to evaluate the propagation of uncertainty in the equation are shown in the following equations:

$$
C Y=\frac{(\text { constant }) m\left(1-\beta^{4}\right)^{1 / 2}}{F a d^{2}(\rho \Delta p)^{1 / 2} t}
$$




$$
\begin{aligned}
u_{c}(C Y)^{2}= & \left(\frac{\delta C Y}{\delta m} u(m)\right)^{2}+\left(\frac{\delta C Y}{\delta t} u(t)\right)^{2}+\left(\frac{\delta C Y}{\delta D} u(D)\right)^{2}+\left(\frac{\delta C Y}{\delta d} u(d)\right)^{2}+ \\
& \left(\frac{\delta C Y}{\delta \rho} u(\rho)\right)^{2}+\left(\frac{\delta C Y}{\delta \Delta p} u(\Delta p)\right)^{2}+\left(\frac{\delta C Y}{\delta F a} u(F a)\right)^{2},
\end{aligned}
$$

where

$$
\begin{gathered}
\frac{\delta C Y}{\delta m}=\frac{C Y}{m}, \\
\frac{\delta C Y}{\delta t}=-\frac{C Y}{t}, \\
\frac{\delta C Y}{\delta p}=-\frac{C Y}{2 p}, \\
\frac{\delta C Y}{\delta \Delta p}=-\frac{C Y}{2 \Delta p}, \\
\frac{\delta C Y}{\delta D}=\frac{-2 C Y \beta^{4}}{\left(1-\beta^{4}\right) D}, \\
\frac{\delta C Y}{\delta d}=-\frac{2 C Y}{d}\left[\frac{\beta^{4}}{1-\beta^{4}}+1\right] \\
\frac{\delta C Y}{\delta F a}=-\frac{C Y}{F a}, \\
u(F a)=1.51 \times 10^{-5} u(T) .
\end{gathered}
$$

Therefore, uncertainties in the calculation of discharge coefficients are calculated by solving the following equation with the appropriate uncertainties for all variables. We combined the Type A and Type B uncertainties prior to this calculation: 


$$
\begin{gathered}
\left(\frac{u_{c}(C Y)}{C Y}\right)^{2}=\left(\frac{u(m)}{m}\right)^{2}+\left(\frac{-u(t)}{t}\right)^{2}+\left(\frac{-2 \beta^{4}}{D\left(1-\beta^{4}\right)} u(D)\right)^{2}+\left(\frac{-2}{d}\left[\frac{\beta^{4}}{1-\beta^{4}}+1\right] u(d)\right)^{2}+ \\
\left(\frac{-u(\rho)}{2 \rho}\right)^{2}+\left(\frac{-u(\Delta p)}{2 \Delta p}\right)^{2}+\left(\frac{-1.51 \times 10^{-5} u(T)}{F_{a}}\right)^{2}
\end{gathered}
$$

Tables 11 and 12 provide a detailed description of the components in the uncertainty calculations of discharge coefficient for two differential transducers. Table 11 lists the uncertainties when the weigh tank is used for mass measurement. Table 12 lists uncertainties when the turbine is used for mass measurement. 


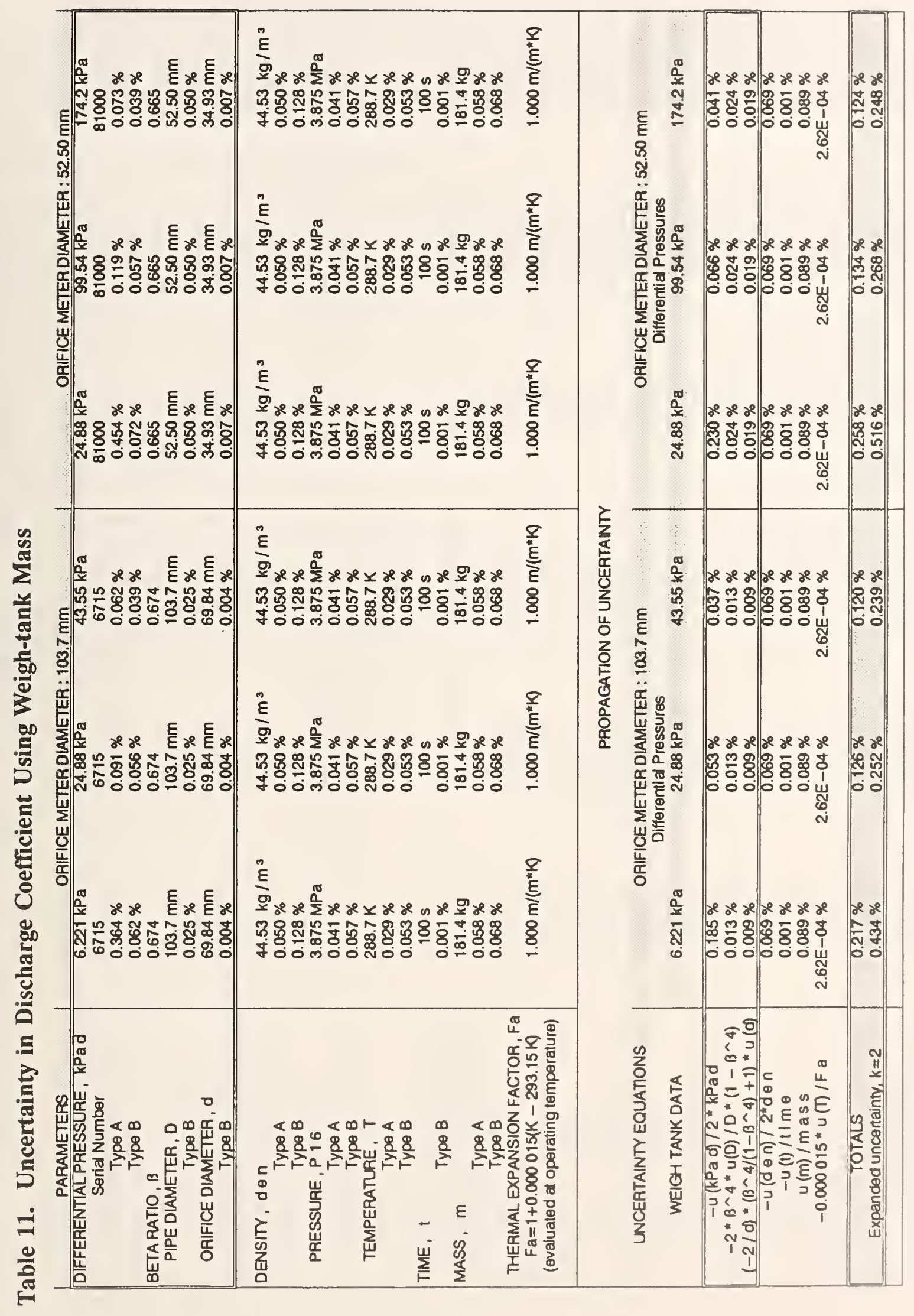




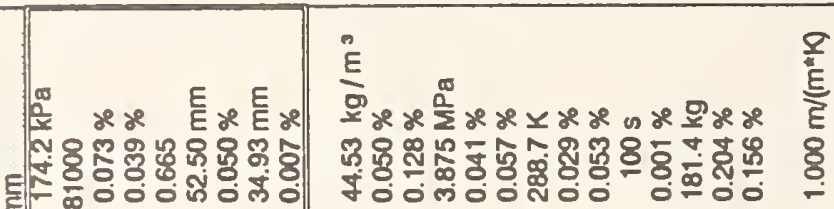

ถึ่

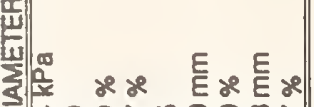

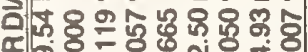

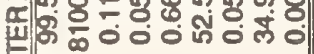

ह

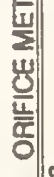

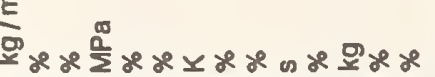

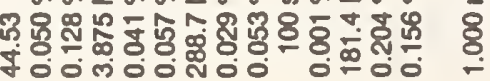

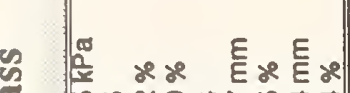

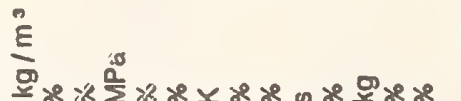

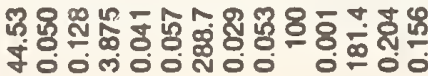

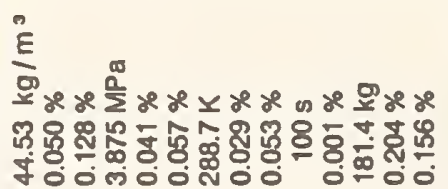

$\frac{8}{\underline{2}}$

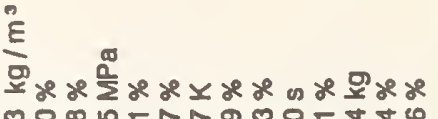

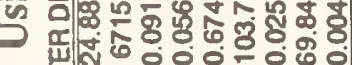

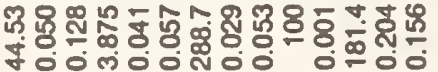

敢

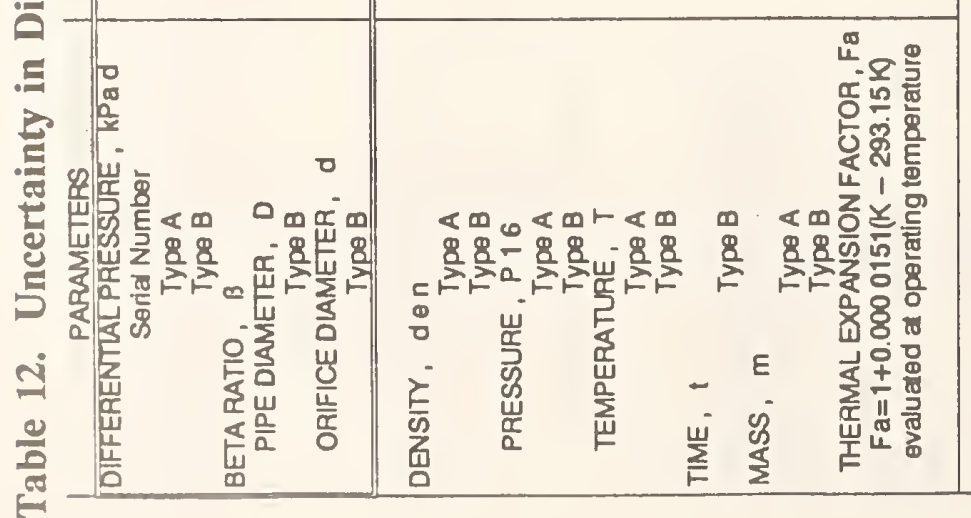

$\sec x+2 x+x$

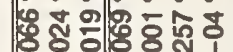

四。

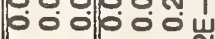

w:

岁宫

萑

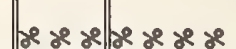

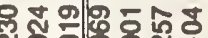

(1)

ส

○.0.



$$
\text { }
$$

है

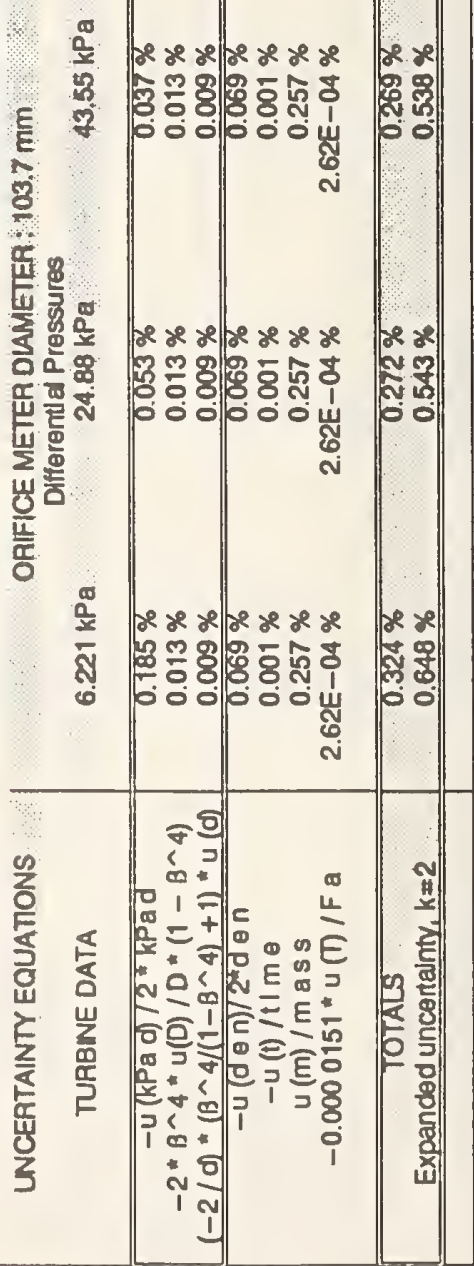




\section{Summary}

Table 13 lists what we consider to be important overall uncertainties associated with this laboratory. These values are an estimate of a 95 percent confidence interval using a coverage factor of 2 . Once again, values both with and without the contribution of the density uncertainty due to MIPROPS are given.

Table 13. Uncertainty (10) Summary

\begin{tabular}{||c|c|c|}
\hline Flow Measurement Uncertainty & \multicolumn{2}{|c|}{ Evaluated for $181.4 \mathrm{~kg}$ mass, $100 \mathrm{~s}(\mathrm{k}=2)$} \\
\hline Device: Weigh tank & With MIPROPS & Without MIPROPS \\
\hline $\mathrm{LN}_{2}$ mass flow & $0.170 \%$ & $0.170 \%$ \\
\hline $\mathrm{LN}_{2}$ volume flow & $0.530 \%$ & $0.178 \%$ \\
\hline $\mathrm{N}_{2}$ gas mass flow & $0.179 \%$ & $0.179 \%$ \\
\hline Device: Turbine & & \\
\hline Gas $\mathrm{N}_{2}$ mass flow & $0.513 \%$ & $0.473 \%$ \\
\hline
\end{tabular}

The uncertainty in discharge coefficient calculation, a component of which is mass flow rate, is variable and is better illustrated by plotting the relationship between uncertainty and pressure differential for the transducers described in this report. Figure 3 demonstrates this more complex uncertainty evaluation (MIPROPS uncertainty included).

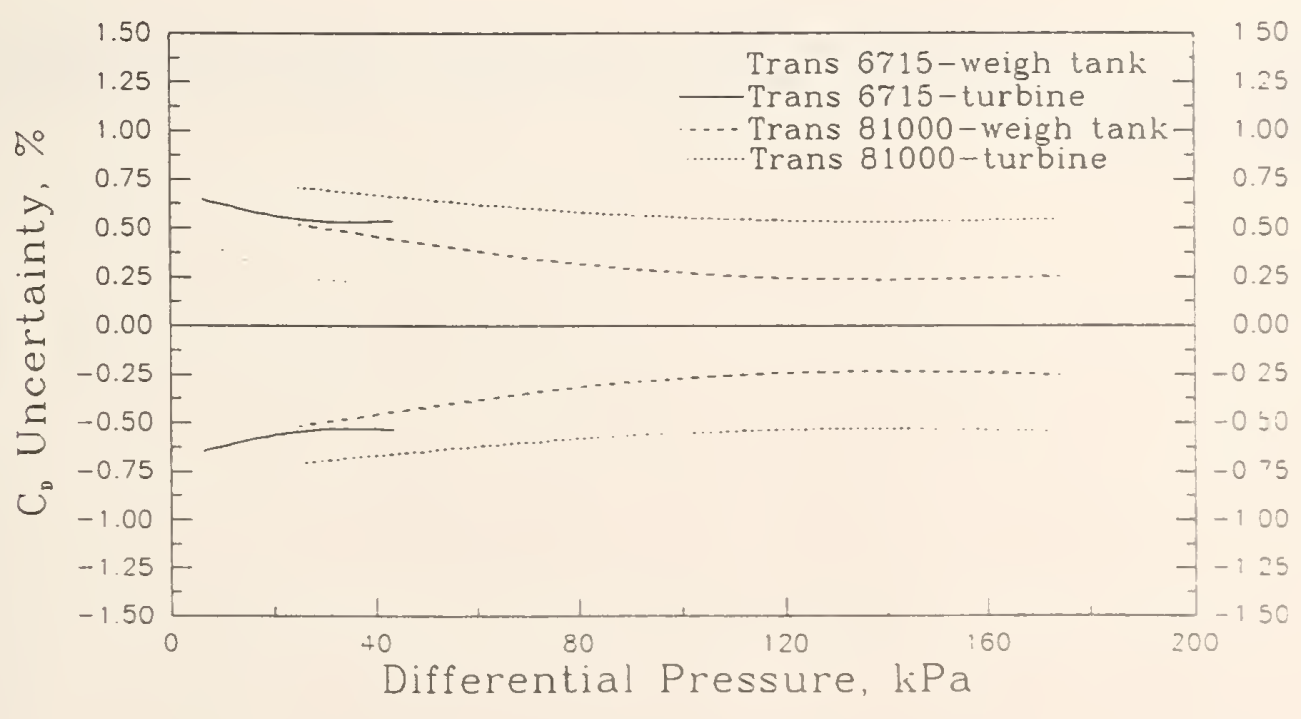

Figure 3. Discharge Coefficient Uncertainty vs. Differential Pressure 


\section{Acknowledgements}

We acknowledge the assistance of Mary Yannutz in document preparation, Jim Brennan for technical support, and Jolene Splett from the NIST Statistical Engineering Division for statistical expertise.

\section{References}

[1] Taylor, B.N.; and Kuyatt, C.E., Guidelines for evaluating and expressing the uncertainty of NIST measurement results, Natl. Inst. Stand. Technol. Tech. Note 1297, 1993.

[2] Mann, D.B.; Dean, J.W.; Brennan, J.A.; and Kneebone, C.H., Cryogenic flow research facility, Natl. Bur. Stand. (U.S.) Report 9749, 1970.

[3] Dean, J.W.; Brennan, J.A.; Mann, D.B.; and Kneebone, C.H., Cryogenic flow research facility provisional accuracy statement, Natl. Bur. Stand. (U.S.) Tech. Note 606, 1971.

[4] DeVaney, W.D.; Dalton, B.J.; and Meeks, J.C. Jr., Vapor-liquid equilibria of the helium-nitrogen system, J. Chem. Eng., Data, 8, No. 4, 1963 October.

[5] NIST Pure fluids database [MIPROPS], Natl. Inst. Stand. Technol. 1986.

[6] Younglove, B.A., Thermophysical properties of fluids. I. Argon, ethylene, parahydrogen, nitrogen, nitrogen triflouride, and oxygen, J. Phy. Chem. Ref. Data, $11,1982$.

[7] Chueh, P.L; and Prausnitz, J.M., Vapor-liquid equilibria at high pressures: Calculation of partial molar volumes in non-polar liquid mixtures, AIChE J., 13, 1099-1107, 1967. 


\section{APPENDIX A. LOAD CELL CALIBRATION WEIGHTS REPORTS AND UNCERTAINTIES}

The load cell calibration weights are four nominal $113.4 \mathrm{~kg}(250 \mathrm{lb})$ brass cylinders. These weights have been calibrated three times by NIST and by the Colorado Department of Agriculture. The calibration reports are included on the following pages. A summary of the calibration history is given in Table A.1, using the units of measurement (lb) provided by the calibrating agency.

Table A.1. Uncertainty ( $1 \sigma)$ in Calibration Weights

\begin{tabular}{|c|c|c|c|c|c|}
\hline Date & Weight \#1 & Weight \#2 & Weight \#3 & Weight \#4 & Uncert. \\
\hline $2-25-70$ & 255.34 & 247.72 & 252.33 & 247.53 & $0.01 \%$ \\
\hline $10-21-71$ & 255.34 & 247.72 & 252.33 & 247.53 & $0.01 \%$ \\
\hline $8-2-78$ & 255.3371 & 247.7215 & 252.3294 & 247.5275 & $0.002 \%$ \\
\hline
\end{tabular}

The 1978 calibration performed by the Colorado Department of Agriculture states that the random uncertainty is negligible and the uncertainty is from known bias uncertainties, Type B. The value of 0.002 percent will be used as the uncertainty due to the weights. The weights did not change over an eight year period and we believe that they have remained constant since that time. The weights have been corrected for local gravity and the buoyancy of air. 


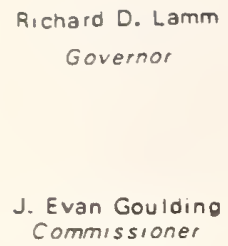

Donald L. Svedman Deputr Commissioner

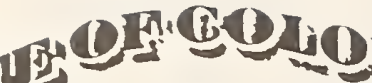 \\ (1) 13

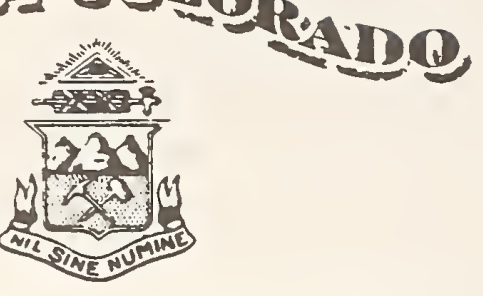 \\ COLORADO DEPARTMENT OF AGRICULTURE \\ 406 STATE SERVICES BUILDING \\ 1525 SHERMAN STREET \\ DENVER, COLORADO 80203 \\ August 2, 1978 \\ REPORT OF TEST \\ for \\ Four special purpose test weights \\ AGRICULTURAL COMMISSION \\ Clarence Stone, Center \\ Chairman \\ William A. Stephens, Gypsum \\ Vice-Chairman \\ Ben Easiman. Hotchkiss \\ John L. Mallov. Denver \\ M. C. McCormick, Holly \\ Elton Miller, Fort Lupton \\ Kay D. Morison. Fleming \\ William H. Webster, Greeley \\ Kenneth G. Wilmore, Denver
}

OWNER: National Bureau of Standards, Cryogenic Laboratory Boulder, Colorado

SUBMITTED BY: J A Brennan

The test weights described above have been compared with the Standards of the State of Colorado and the following results have been determined:
Weight \#1
255.3371 lbs
Uncertainty $0.0052 \mathrm{lb}$.
$\# 2$
247.7215
252.3294
\#3
247.5275

Cert. No: 4455

The uncertainty figure is an expression of the overall uncertainty using three standard deviations as a limit to the effect of random errors of measurement, the magnitude of systematic errors from known sources being negligible.

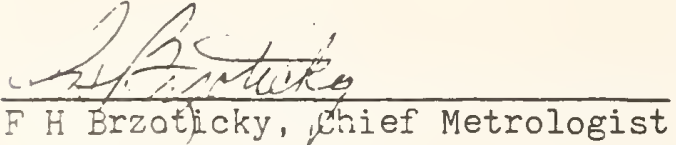

Colorado Depar,tnent of Agriculture

Metrology Laboratory

3125 Wyandot St.

Denver, Colorado 80211
THESE CERTIFICATICNS ARE TRACEABLE TO THE IUATIONAL GUREAU CF STAIIEARDS.

A.LL CERTIFICATES ISSUED BY THE COLORADD EPPRTMEINT OF AGR!CULTURE-METROLOGY LABCPRTGPY EXPIRE ONE YEAR FROM THE DATE DF ISSUANCE 
Date: October 12, 1971

Reply to: John Shafer, 272.55
Attn of:

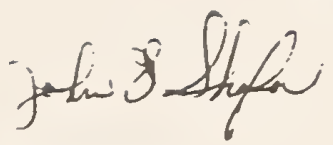

subject: Calibration of Brass Cylinders

To: Jim Brennan, 275.06

Four brass cylinders were compared to weights traceable to the National Standards and were found to be as follows:

$$
\begin{array}{ll}
\text { \#1 } & 255.34 \mathrm{lbs} . \\
\# 2 & 247.72 \mathrm{lbs} . \\
\# 3 & 252.33 \mathrm{lbs} . \\
\# 4 & 247.53 \mathrm{lbs} .
\end{array}
$$

The weights are identified by numbers stamped at intervals around the circumference of the cylinders.

The measurements were made March 4, 1971.

The data given above is correct to \pm 0.01 percent.

Six hours were charged to 2750161. 
UNITED STATES GOVERNMENI

Memorandum

To : John Dean

275.06

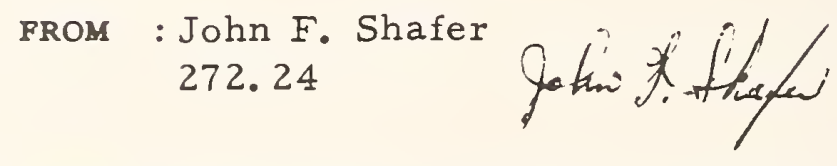

SUBJECT: Calibration of Brass Cylinders
U.S. DEPARTMENT OF COMMERCE NATIONAL BUREAU OF STANDARDS

Boulder, Colorado 80302

\section{In reply refer to:}

Four brass cylinders were compared to weights traceable to the National Standards and found to be as follows:

$\begin{array}{ll}\text { \# } 1 & 255.34 \text { lbs. } \\ \# 2 & 247.72 \text { lbs. } \\ \# 3 & 252.33 \text { lbs. } \\ \# 4 & 247.53 \text { lbs. }\end{array}$

The weights are identified by numbers stamped at intervals around the circumference of the cylinders.

The data given above is correct to \pm 0.01 percent.

7 hours was charged to Project No. 2750360, work order No. 0156. 


\section{APPENDIX B. NITROGEN PROPERTY UNCERTAINTY}

Depending on the location in the flow system, we are measuring subcooled liquid nitrogen or gaseous nitrogen (supercritical) flow. The properties of these fluids are calculated using a computerized package, NIST Pure Fluids Database (MIPROPS) [5]. The nitrogen property information in the database was taken from a report by B. A. Younglove [6]. The uncertainty expressed by Younglove for the density values of nitrogen were $2 \sigma$, therefore, the uncertainties that we list in our table are the stated uncertainties divided by 2. The density uncertainties are different for the two phases of nitrogen that are in our system. Table B.1 lists the uncertainties in the density. We also include the change in density associated with small changes in temperature and pressure. These values are used to evaluate density uncertainties in various regions of the flow system using the Type A and Type B uncertainties associated with temperature and pressure measurements.

Table B.1. Uncertainties (1o) in Nitrogen Properties

\begin{tabular}{||l|l|l|}
\hline \hline Property Uncertainties & $\begin{array}{l}\text { Liquid Nitrogen } \\
\mathrm{T}=85 \mathrm{~K}, \mathrm{P}=621 \mathrm{kPa}\end{array}$ & $\begin{array}{l}\text { Gaseous Nitrogen } \\
\mathrm{T}=288.7 \mathrm{~K}, \mathrm{P}=3.87 \mathrm{MPa}\end{array}$ \\
\hline $\begin{array}{l}\text { MIPROPS } \\
\text { Density }\end{array}$ & $0.25 \%$ & $0.10 \%$ \\
\hline$\delta \rho /\left.\delta \mathrm{T}\right|_{\mathrm{P}}$ & $0.703 \%$ per $\mathrm{K}$ & $0.378 \%$ per $\mathrm{K}$ \\
\hline$\delta \rho /\left.\delta \mathrm{P}\right|_{\mathrm{T}}$ & $0.0005 \%$ per $\mathrm{kPa}$ & $0.025 \%$ per $\mathrm{kPa}$ \\
\hline
\end{tabular}




\section{APPENDIX C. UNCERTAINTIES IN ELECTRONIC INSTRUMENTATION}

Most of the uncertainties described in this Appendix are those stated by the manufacturers of the instruments. As outlined in Technical Note 1297 [1], we have assumed that the stated manufacturers' uncertainties are based on a rectangular distribution which has a standard uncertainty equal to the half-width of the specified interval divided by the square root of 3. A description of the instruments follows, and Table C. 1 is a composite of the Type B uncertainties that are incorporated into other calculations.

\section{Multi-function Datalogger}

The datalogger is used for several purposes. It measures the output of the constantcurrent source, it supplies current to, and measures the voltage output from, two thermometers located in the liquid catch tank ullage, and it measures elapsed time during a test point.

\section{Computer Analog to Digital Converter}

The computer analog to digital (A/D) converter reads voltage outputs from as many as 80 analog transmitters. Almost every transmitter in both the liquid and gas phase of the flow loop is connected to this I/O device. All channels can be read at an approximate rate of 100 times per second. Because of the resolution of this instrument, it provides the greatest contribution to uncertainty of any electronic instrument.

\section{Universal Counter}

The universal counter counts the total number of pulses from any pulse-type meter (turbine) in the gas flow system. 
Table C.1. Electronic Instruments Uncertainties ( $1 \sigma)$ Quoted by Manufacturers

\begin{tabular}{|l|c|c||}
\hline Instrument & Nominal Value & Type B Uncertainty \\
\hline Datalogger: & & \\
A/D Converter & $0.1 \mathrm{~V}$ & $0.0040 \%$ \\
& $1.0 \mathrm{~V}$ & $0.0035 \%$ \\
& $10.0 \mathrm{~V}$ & $0.0035 \%$ \\
& & $0.001 \mathrm{~s}$ \\
Timer & Variable & \\
\hline Computer & Range: & $2.89 \mathrm{mV}$ \\
A/D Converter & $5.12-10.24 \mathrm{~V}$ & $1.44 \mathrm{mV}$ \\
& $2.56-5.11 \mathrm{~V}$ & $0.72 \mathrm{mV}$ \\
& $1.28-2.55 \mathrm{~V}$ & $0.036 \mathrm{mV}$ \\
\hline Universal Counter & $0.0-1.27 \mathrm{~V}$ & $1 \mathrm{pulse}$ \\
\hline
\end{tabular}

\section{Constant-Current Source}

The constant-current source is used to supply current to the platinum resistance thermometers (PRT) located throughout the liquid and gas systems. The calculated current is used during the calibration of the PRTs and during temperature measurement with the PRTs. The current is determined by the datalogger which measures the voltage across a precision resistor; therefore, the uncertainty associated with the current to PRTs is actually a combination of the datalogger and resistor uncertainties.

We evaluate the uncertainty in a $1 \mathrm{~mA}$ signal, the nominal current supplied to all PRTs. The Type B component of this uncertainty is a combination of the datalogger and resistor uncertainties. The Type A component of this uncertainty is the standard deviation of a sample of readings from the constant current source. These uncertainties will be used in the propagation of uncertainties for PRTs in Appendix F.

Table C.2. Uncertainty $(1 \sigma)$ in $1 \mathrm{~mA}$ Current Measurement

\begin{tabular}{||l|c|c||}
\hline \hline Current Uncertainty & Type A & Type B \\
\hline Evaluated: $0.1 \mathrm{~V}, 100 \Omega$ & $0.00097 \%$ & $0.0126 \%$ \\
\hline
\end{tabular}

${ }^{1}$ Uncertainties are calculated based on voltages at the nominal value under consideration. 


\section{APPENDIX D. UNCERTAINTIES OF QUARTZ BOURDON GAUGES USED AS CALIBRATION PRESSURE STANDARD}

Quartz Bourdon gauges are highly accurate pressure standards used to calibrate differential and static pressure transducers. The differential pressure transducers measure the pressure drop across an orifice plate, and static pressure transducers measure line pressure. The interlaboratory device we use to calibrate the Bourdon gauges is a deadweight tester calibrated by NIST. These calibrations have shown the Bourdon gauges to be extremely stable over time. The resultant uncertainties from these calibrations are smaller than those stated by the manufacturer, but, for simplicity, we have decided to take a more conservative route and use the uncertainties supplied by the manufacturer. The contribution of the uncertainty in these instruments to overall uncertainty in pressure measurement is minimal.

The manufacturers' uncertainties for these instruments are defined as a percentage of the range of the instrument and the reading at a specific pressure. The output of the instrument, read by the datalogger, is a voltage which is proportional to pressure. As outlined in Technical Note 1297 [1], we have assumed that the stated manufacturers' uncertainties are based on a rectangular distribution which has a standard uncertainty equal to the half-width of the specified interval divided by the square root of three. The Type B uncertainties $(1 \sigma)$ for these instruments are:

\section{$0.0017 \%$ Range \\ $0.0030 \%$ Reading}

The contribution of the uncertainties of these instruments to the uncertainty in pressure measurements are calculated based on nominal pressures under consideration. These nominal pressures are shown in the tables associated with each transducer found in Appendix E. 


\section{APPENDIX E. UNCERTAINTIES IN PRESSURE SENSING INSTRUMENTS}

The uncertainty in pressure measurement has many components. They include the standard error of the estimate of the calibration equation, uncertainties in the calibration standard (Appendix D), uncertainties in all electronic equipment (Appendix C), as well as dynamic variability observed during data points. The output from the static and differential pressure transducers are digitized by the computer A/D converter. The data acquisition channels and cables for the transducers are the same during calibration and actual operating conditions. The signal from the quartz Bourdon gauge is read by the datalogger.

The dynamics of pipe flow create variabilities in the signals from the pressure transducers that are not present during calibrations. We evaluated the dynamic variability of the transducers by analyzing a sample of mean output values for the both the static and differential transducers. Each value in the sample represents the mean of the readings taken during a measurement (50 to 400 readings), and we analyzed at least 57 values for each transducer.

Because static or line pressures vary little from data point to data point, the standard errors of the means $(\mathrm{s} / \sqrt{\mathrm{n}})$ for the sample of static pressure values were averaged. The average was used as the dynamic uncertainty. We divided the dynamic uncertainty by a nominal pressure for each transducer to determine the fractional uncertainty in pressure measurement as a result of flow dynamics.

A slightly different approach was used to evaluate the dynamic variabilities in the differential pressure transducers. The standard error of the means of the differential pressure measurements were fitted versus the mean differential pressures. Using this fit, we determined the dynamic uncertainty at specific differential pressures shown in Tables E.6 and E.7.

\section{Atmospheric and Static Pressure}

The barometer which measures ambient air pressure is also calibrated with the quartz Bourdon-tube gauge. The barometer reading is used for calibrating the static pressure transducers and its uncertainty contributes to the uncertainty in the static pressure measurement. The pressure range measured by static pressure transducers varies from 3.72 to $4.0 \mathrm{MPa}$ (540 to $580 \mathrm{psia}$ ). The uncertainty for these transducers will be evaluated at a nominal pressure of $3.87 \mathrm{MPa}$ (562 psia). The following tables outline the uncertainties associated with the static pressure transducers. 
Table E.1. Barometer Uncertainties (1 $\sigma$ )

\begin{tabular}{|l|l|l|}
\hline $\begin{array}{l}\text { Barometer Uncertainties } \\
\text { (Evaluated @ 87.9 kPa) }\end{array}$ & Type A & Type B \\
\hline Calibration Equation & $0.0062 \%$ & \\
\hline Quartz Bourdon Gauge & & $0.0047 \%$ \\
\hline Datalogger A/D & & $0.0014 \%$ \\
\hline Computer A/D & & $0.046 \%$ \\
\hline Total (in quadrature) & $0.0062 \%$ & $0.046 \%$ \\
\hline
\end{tabular}

Table E.2. Uncertainties (10) in Orifice Meter Static Pressure Transducer

\begin{tabular}{||l|l|l|}
\hline $\begin{array}{l}\text { Orifice Static Pressure } \\
\text { Uncertainties } \\
(\mathrm{P}=3.87 \mathrm{MPa})\end{array}$ & Type A & Type B \\
\hline Calibration Equation & $0.0405 \%$ & \\
\hline Quartz Bourdon Gauge & & $0.0046 \%$ \\
\hline Datalogger A/D & & $0.0035 \%$ \\
\hline Computer A/D & & $0.034 \%$ \\
\hline Barometer (87.9 kPa) & $0.0062 \%$ & $0.046 \%$ \\
\hline Flow Dynamics & $0.002 \%$ & \\
\hline Total (in quadrature) & $0.041 \%$ & $0.057 \%$ \\
\hline
\end{tabular}


Table E.3. Uncertainties (1 $\sigma$ ) in Turbine Meter Static Pressure Transducer

\begin{tabular}{||l|l|l|}
\hline $\begin{array}{l}\text { Turbine Static Pressure } \\
\text { Uncertainties } \\
(\mathrm{P}=3.87 \mathrm{MPa})\end{array}$ & Type A & Type B \\
\hline Calibration Equation & $0.0265 \%$ & \\
\hline Quartz Bourdon Gauge & & $0.0046 \%$ \\
\hline Datalogger A/D & & $0.0035 \%$ \\
\hline Computer A/D & & $0.056 \%$ \\
\hline Barometer (87.9 kPa) & $0.0062 \%$ & $0.046 \%$ \\
\hline Flow Dynamics & $0.002 \%$ & \\
\hline Total (in quadrature) & $0.027 \%$ & $0.073 \%$ \\
\hline
\end{tabular}

Table E.4. Uncertainties (10) in Liquid Test Section Static Pressure Transducer

\begin{tabular}{||l|l|l|}
\hline \hline $\begin{array}{l}\text { P7 } \mathrm{LN}_{2} \text { Static Pressure } \\
\text { Uncertainties (P=586 kPa) }\end{array}$ & Type A & Type B \\
\hline Calibration Equation & $0.061 \%$ & \\
\hline Quartz Bourdon Gauge & & $0.014 \%$ \\
\hline Datalogger A/D & & $0.0035 \%$ \\
\hline Computer A/D & & $0.034 \%$ \\
\hline Barometer (87.9 kPa) & $0.0062 \%$ & $0.046 \%$ \\
\hline Flow Dynamics & $0.03 \%$ & \\
\hline Total (in quadrature) & $0.068 \%$ & $0.059 \%$ \\
\hline \hline
\end{tabular}

We did not perform the same dynamic analysis for transducer P9, located in the weigh tank, because we do not keep the same level of archival data for P9. However, we estimate the results would be comparable to those in $\mathrm{P7}$ because the transducers are similar and are located in similar environments. 


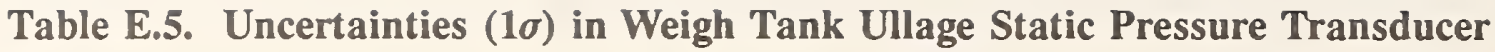

\begin{tabular}{||l|l|l|}
\hline \hline $\begin{array}{l}\text { P9 Ullage Static Pressure } \\
\text { Uncertainties }(\mathrm{P}=517 \mathrm{kPa})\end{array}$ & Type A & Type B \\
\hline Calibration Equation & $0.047 \%$ & \\
\hline Quartz Bourdon Gauge & & $0.015 \%$ \\
\hline Datalogger A/D & & $0.0035 \%$ \\
\hline Computer A/D & & $0.038 \%$ \\
\hline Barometer (87.9 kPa) & $0.0062 \%$ & $0.046 \%$ \\
\hline Flow Dynamics & $0.030 \%$ & \\
\hline Total (in quadrature) & $0.056 \%$ & $0.062 \%$ \\
\hline
\end{tabular}

\section{Differential Pressure Transducers}

Differential pressure transducers measure the pressure drop across an orifice plate and are designed for certain pressure ranges. The pressure range required is a function of pipe size, beta ratio, and flow rate. From one to four differential pressure transducers are used at one time and are read simultaneously. We evaluated the uncertainty of several transducers that cover various differential pressure ranges and have selected two transducers with the greatest uncertainty to provide a conservative estimate of the uncertainty of all transducers of similar use and range. The uncertainty of the transducers also depends upon the differential pressure at which it is operating. We evaluated each transducer at three differential pressures.

Tables E.6 and E.7 list the uncertainties for the differential pressure transducers. 

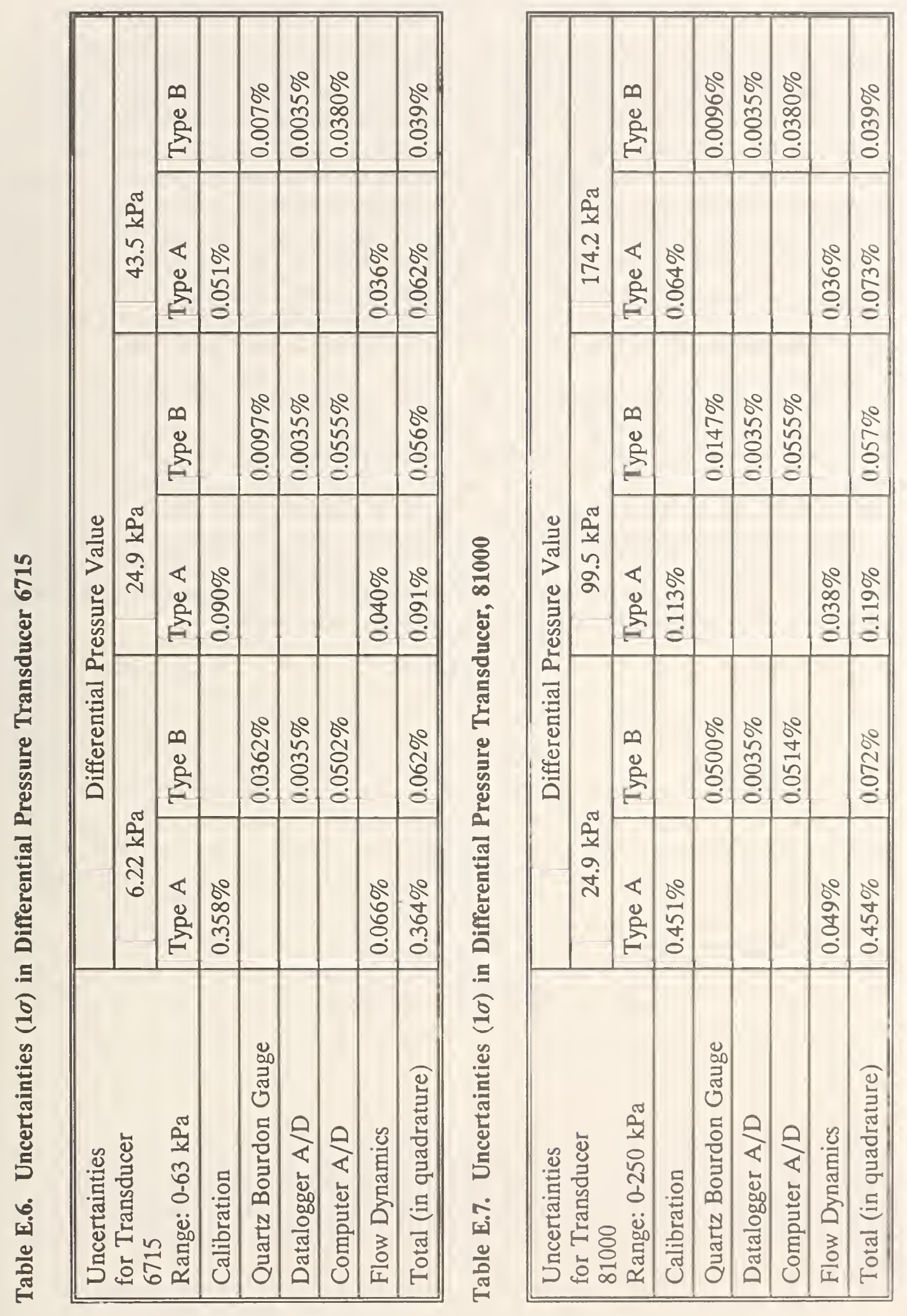


\section{APPENDIX F。 UNCERTAINTIES IN TEMPERATURE MEASUREMENT}

We use platinum resistance thermometers (PRTs) to measure temperatures critical to accurate flow measurement. They are calibrated against our interlaboratory standard platinum resistance thermometer (SN 480) that was calibrated by the NIST Thermometry Group, Process Measurement Division. The calibration of system thermometers consists of supplying a constant current to the PRTs in series with SN 480 and the precision resistor (for the current measurement). The PRTs are immersed in baths at various temperatures which reflect the temperatures at which the PRTs will operate within the flow system. The voltage across the PRTs is amplified before being digitized by the computer's A/D converter. The voltage across SN 480 is digitized by a high resolution multi-function datalogger which transmits the digitized voltage to the computer via an IEEE 488 databus. The voltage across the precision resistor used for calculating the current is digitized by the datalogger, also.

A linear least-squares regression fit of the voltage from the PRTs and the temperature calculated from SN 480 is performed over the temperature range of interest. This calibration is used in the data reduction of temperature measurements. In the flow measurement process, the thermometers remain in the same series and on the same A/D converter channels as used for calibration. SN 480 is the only item removed from the system. The uncertainty associated with the thermometers includes the uncertainty due to the calibration equation as well as the propagation of uncertainties of current and voltage in the calibration equation, and the uncertainty of SN 480. The equations used to perform the propagation of uncertainty for the thermometers are listed below:

$$
\begin{gathered}
T=A+B(V / I) \\
\frac{\delta T}{\delta V}=\frac{B}{I} \\
\frac{\delta T}{\delta I}=\frac{-B V}{I^{2}} \\
u(T)^{2}=B^{2}\left[\left(\frac{u(V)}{I}\right)^{2}+\left(\frac{V}{I^{2}} u(I)\right)^{2}\right] .
\end{gathered}
$$

We identify six PRTs that we consider important to our determination of system uncertainty. Any uncertainties in temperature measurement ultimately contribute to uncertainties in density calculations. For this reason, temperature uncertainties have been evaluated in kelvins. These values are then used to evaluate a component of density uncertainty. 
We consider three of these thermometers critical to accurate flow measurement: $\mathrm{T} 16$, the orifice meter thermometer, $\mathrm{T} 17$, the turbine meter thermometer, and $\mathrm{T} 10$, the liquid test section thermometer. T10 is calibrated between $76 \mathrm{~K}$ and $85 \mathrm{~K}$, and T16 and T17 are calibrated between $273.15 \mathrm{~K}$ and $305 \mathrm{~K}$. Tables F.1 through F.3 illustrate all known components of uncertainty for these thermometers.

Table F.1. Uncertainties (1 $\sigma)$ in Orifice Meter PRT, T16

\begin{tabular}{|l|c|c|}
\hline $\begin{array}{l}\text { T16-Orifice PRT } \\
\text { (Evaluated at 288.7 K) }\end{array}$ & Type A & Type B \\
\hline Standard PRT (SN 480) & & $0.0001 \%$ \\
\hline Voltmeter for SN 480 & & $0.0014 \%$ \\
\hline Calibration & $0.028 \%$ & \\
\hline $\begin{array}{l}\text { Propagation of Uncertainties } \\
(\mathrm{T}=\mathrm{A}+\mathrm{B}(\mathrm{V} / \mathrm{I}) \text { ) }\end{array}$ & $0.0037 \%$ & $0.0528 \%$ \\
\hline At $288.7 \mathrm{~K}$ & $0.082 \mathrm{~K}$ & $0.152 \mathrm{~K}$ \\
\hline
\end{tabular}

Table F.2. Uncertainties (1 $\sigma$ ) in Turbine Meter PRT, T17

\begin{tabular}{||l|l|l|}
\hline $\begin{array}{l}\text { T17-Turbine PRT } \\
\text { (Evaluated at 288.7 K) }\end{array}$ & Type A & Type B \\
\hline Standard PRT (SN 480) & & $0.0001 \%$ \\
\hline Voltmeter for SN 480 & & $0.0014 \%$ \\
\hline Calibration & $0.028 \%$ & $0.0527 \%$ \\
\hline $\begin{array}{l}\text { Propagation of Uncertainties } \\
(\mathrm{T}=\mathrm{A}+\mathrm{B}(\mathrm{V} / \mathrm{I}))\end{array}$ & $0.0037 \%$ & $0.152 \mathrm{~K}$ \\
\hline At $288.7 \mathrm{~K}$ & $0.082 \mathrm{~K}$ & \\
\hline
\end{tabular}


Table F.3. Uncertainties ( $1 \sigma)$ in Liquid Test Section PRT, T10

\begin{tabular}{|l|l|l|}
\hline $\begin{array}{l}\text { T10-Liquid Test Section PRT } \\
\text { (Evaluated at 85 K) }\end{array}$ & Type A & Type B \\
\hline Standard PRT (SN 480) & & $0.0001 \%$ \\
\hline Voltmeter for SN 480 & & $0.0014 \%$ \\
\hline Calibration & $0.041 \%$ & $0.021 \%$ \\
\hline $\begin{array}{l}\text { Propagation of Uncertainties } \\
(\mathrm{T}=\mathrm{A}+\mathrm{B}(\mathrm{V} / \mathrm{I}))\end{array}$ & $0.008 \%$ & $0.018 \mathrm{~K}$ \\
\hline At $85 \mathrm{~K}$ & $0.036 \mathrm{~K}$ & \multicolumn{2}{|l}{} \\
\hline
\end{tabular}

Three other thermometers provide secondary contributions to the buoyancy corrections used in the weigh tank system. T13 measures the temperature of the liquid collected in the weigh tank. The weigh tank temperature is used in the calculation of density and, thereby, volume of the collected liquid. TS71 and TS72 measure the temperature in the ullage gas surrounding the weigh tank and are used in the calculation of ullage gas density. The buoyancy of the liquid in the ullage gas is the product of the liquid volume and the ullage gas density. Though accurate measurement of the ullage gas temperature is important, its contribution to the total system uncertainty is secondary.

Thermometers T13, TS71, and TS72 are located in the catch tank and are not as readily accessible as those located in the flow loop. For that reason, they are not calibrated as frequently. The residual standard deviation of the original calibration of T13 was $0.4 \mathrm{~K}$. Because of the long-term stability of PRTs and the fact that T13 remains in a protected environment free from mechanical shock, we think that the performance has not changed significantly since the original calibration. We chose, however, to use a slightly greater value of $0.5 \mathrm{~K}$ as a conservative Type $\mathrm{B}$ estimate of the total uncertainty in this temperature measurement.

The manufacturer of thermometers TS71 and TS72 provided a one-point calibration by measuring the resistance at $273.15 \mathrm{~K}$. Using the manufacturer's specifications for platinum resistance thermometers of this type, we derived a general second order calibration curve whose independent variable is the ratio of the resistance measured at operating temperatures to the resistance at $273.15 \mathrm{~K}$. A test of this regression fit at liquid nitrogen temperatures indicated a possible 0.5 to $0.8 \mathrm{~K}$ error with regards to temperatures measured by SN 480. We will use a value of $1 \mathrm{~K}$ as a conservative Type B estimate of the total uncertainty in these temperature measurements. Table F.4 lists the uncertainties associated with these thermometers. 
Table F.4. Uncertainties (1o) in Weigh Tank and Ullage PRTs

\begin{tabular}{||l|c|c|}
\hline $\begin{array}{l}\text { Secondary PRT } \\
\text { Uncertainties }\end{array}$ & Type A & Type B \\
\hline T13 & & $0.5 \mathrm{~K}$ \\
\hline TS71, TS72 & & $1.0 \mathrm{~K}$ \\
\hline
\end{tabular}




\section{APPENDIX G. UNCERTAINTIES IN DIMIENSIONAL MEASUREMENTS}

The uncertainties in measurement of pipe diameter and orifice diameter are listed in Table G.1. These values will be used in the propagation of uncertainty for discharge coefficients. The magnitudes of the measurement uncertainties are shown in parenthesis and are evaluated at nominal values of $10.2 \mathrm{~cm}$ (4 in) for pipe diameter and $6.35 \mathrm{~cm}(2.5$ in) for orifice diameter.

Table G.1. Dimensional Uncertainties

\begin{tabular}{||l|l|}
\hline \hline Dimensional Uncertainty & Type B \\
\hline Pipe Diameter $(0.0254 \mathrm{~mm})$ & $0.025 \%$ \\
\hline Orifice Diameter $(0.00254 \mathrm{~mm})$ & $0.004 \%$ \\
\hline
\end{tabular}




\section{Periodical}

Journal of Research of the National Institute of Standards and Technology-Reports NIST research and development in those disciplines of the physical and engineering sciences in which the Institute is active. These include physics, chemistry, engineering, mathematics, and computer sciences. Papers cover a broad range of subjects, with major emphasis on measurement methodology and the basic technology underlying standardization. Also included from time to time are survey articles on topics closely related to the Institute's technical and scientific programs. Issued six times a year.

\section{Nonperiodicals}

Monographs-Major contributions to the technical literature on various subjects related to the Institute's scientific and technical activities.

Handbooks-Recommended codes of engineering and industrial practice (including safety codes) developed in cooperation with interested industries, professional organizations, and regulatory bodies

Special Publications-Include proceedings of conferences sponsored by NIST, NIST annual reports, and other special publications appropriate to this grouping such as wall charts, pocket cards, and bibliographies.

Applied Mathematics Series-Mathematical tables, manuals, and studies of special interest to physicists, engineers, chemists, biologists, mathematicians, computer programmers, and others engaged in scientific and technical work.

National Standard Reference Data Series-Provides quantitative data on the physical and chemical properties of materials, compiled from the world's literature and critically evaluated. Developed under a worldwide program coordinated by NIST under the authority of the National Standard Data Act (Public Law 90-396). NOTE: The Journal of Physical and Chemical Reference Data (JPCRD) is published bimonthly for NIST by the American Chemical Society (ACS) and the American Institute of Physics (AIP). Subscriptions, reprints, and supplements are available from ACS, 1155 Sixteenth St., NW, Washington, DC 20056.

Building Science Series-Disseminates technical information developed at the Institute on building materials, components, systems, and whole structures. The series presents research results, test methods, and performance criteria related to the structural and environmental functions and the durability and safety characteristics of building elements and systems.

Technical Notes-Studies or reports which are complete in themselves but restrictive in their treatment of a subject. Analogous to monographs but not so comprehensive in scope or definitive in treatment of the subject area. Often serve as a vehicle for final reports of work performed at NIST under the sponsorship of other government agencies.

Voluntary Product Standards-Developed under procedures published by the Department of Commerce in Part 10, Title 15, of the Code of Federal Regulations. The standards establish nationally recognized requirements for products, and provide all concerned interests with a basis for common understanding of the characteristics of the products. NIST administers this program in support of the efforts of private sector standardizing organizations.

Consumer Information Series-Practical information, based on NIST research and experience, covering areas of interest to the consumer. Easily understandable language and illustrations provide useful background knowledge for shopping in today's technological marketplace.

Order the above NIST publications from: Superintendent of Documents, Government Printing Office, Washington, DC 20402.

Order the following NIST publications-FIPS and NISTIRs-from the National Techmical Information Service, Springfield, VA 22161.

Federal Information Processing Standards Publications (FIPS PUB)-Publications in this series collectively constitute the Federal Information Processing Standards Register. The Register serves as the official source of information in the Federal Government regarding standards issued by NIST pursuant 10 the Federal Property and Administrative Services Act of 1949 as amended, Public Law 89-306 (79 Stat. 1127), and as implemented by Executive Order 11717 (38 FR 12315, dated May 11, 1973) and Part 6 of Title 15 CFR (Code of Federal Regulations).

NIST Interagency Reports (NISTIR)-A special series of interim or final reports on work performed by NIST for outside sponsors (both government and non-government). In general, initial distribution is handled by the sponsor; public distribution is hy the National Technical lnformation Service. Springfield. VA 22161, in paper copy or microfiche form. 


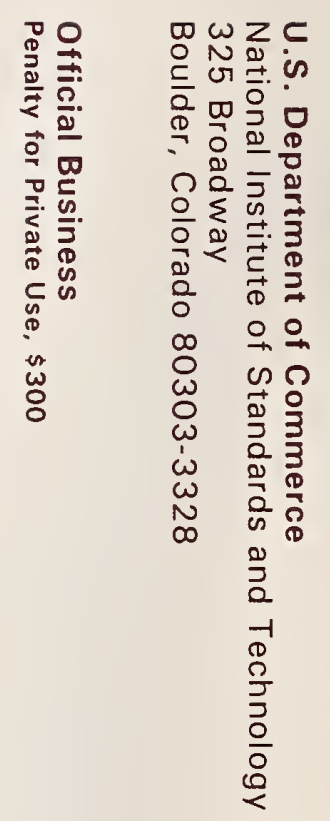

